\title{
آليات الحماية الاجتماعية للمرأة المصرية دراسة على عينة من النسائ الفقيرات
}

\author{
دكتور/ أيمن القرنفيلي \\ كليت الآدابـ جامعتشبنها
}




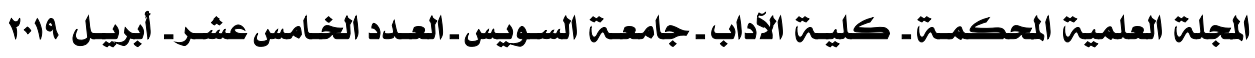




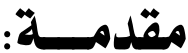

مع بداية الالفية الثالثة تصدرت إثكالية الفقر كافة الاثكاليات الاقتصادية

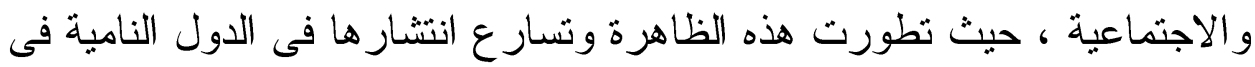

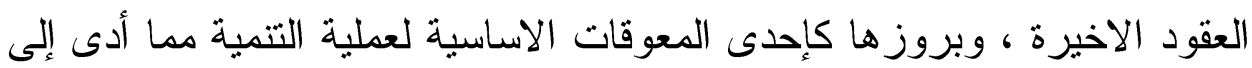

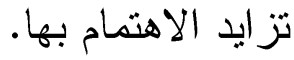

وفى هذا السياق باتت سياسات الحماية الاجتماعية ضرورة ملحسـة ذات

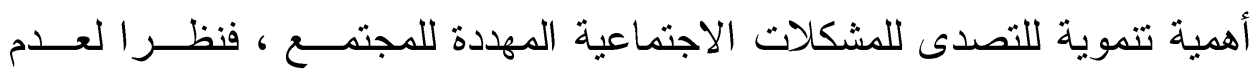

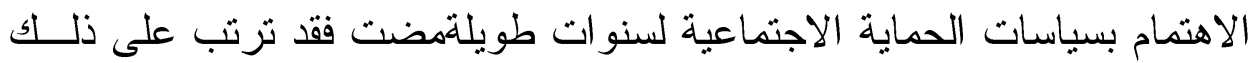
تفاقم مشكلات إجتماعية كثيرة على رأسها مشكلة الفقر وكيفية الحد منه ، و العمل

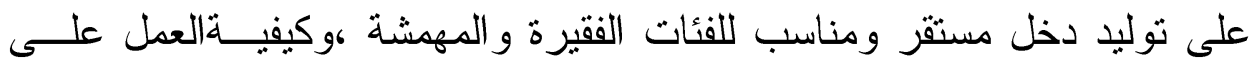

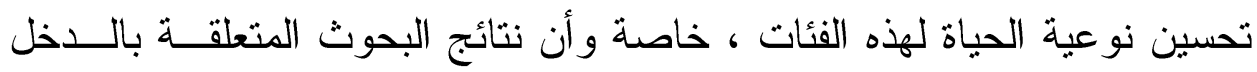

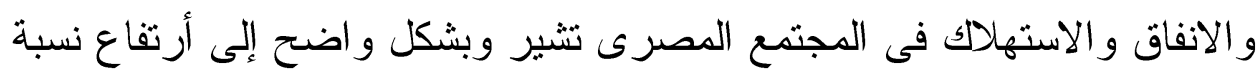

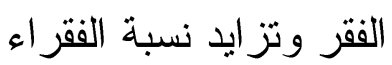

ومن هنايشكل الفقر هاجساً مقلقاً للمجتمعات ويبقى القضاء عليه أحد أهم

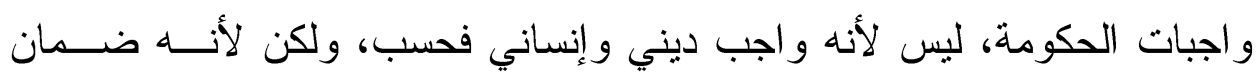

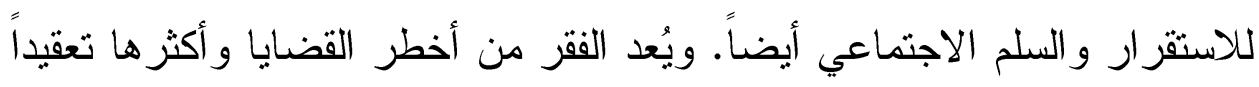

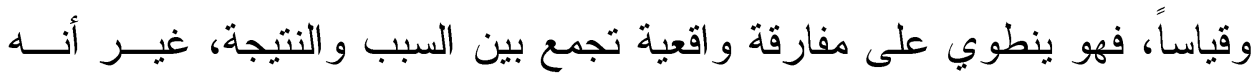

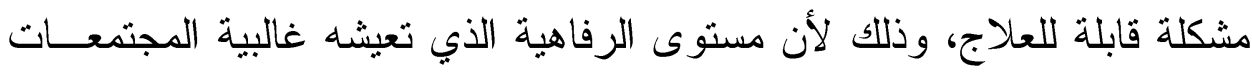

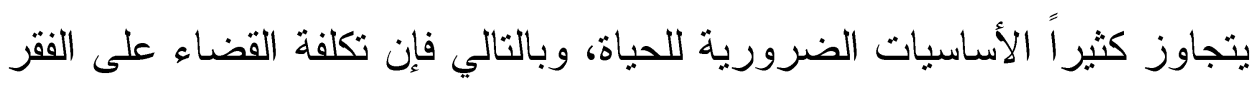

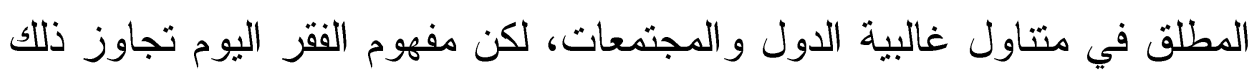

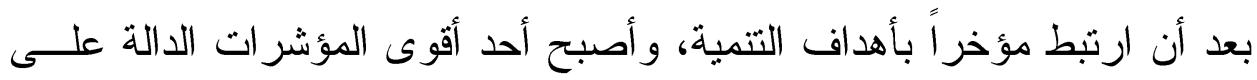
إنجاز اتها على صعيد المجتمع الدولي كافة. وفى هذا السياق تعرضت مصر منذ منتصف التسـعينات مــن القـرن

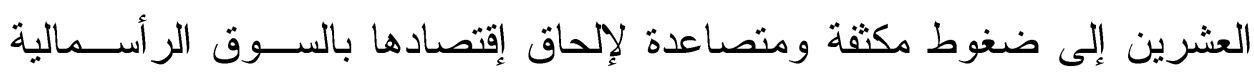

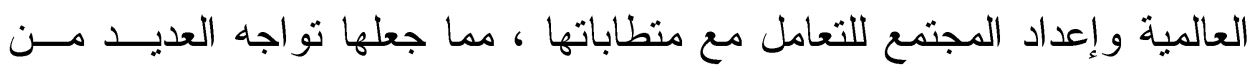


التحديات الجديدة و التى من بينها التكيــف مــع الطبيعــة المتغيــرة للمخــاطر الاجتماعية و الفقر و البطالة الناتجة عن الارتباط العالمى المتز ايد للتجارة وأسواق رأس المال و الحد من التفاوت الاجتماعى والتكنولوجى المتز ايد و العمل على بناء إر ادة وطنية قادرة على توفير الموارد اللازمة للحماية الاجتماعية . وبالرغم من أن ضرر إعادة هيكلة أسواق العمل شمل النشيطين من كلا وفيل

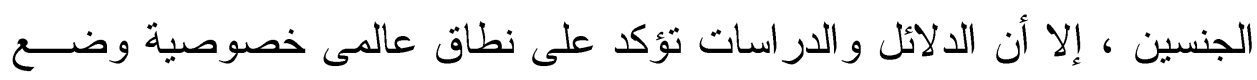

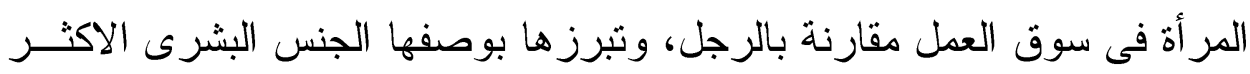
تضررا ومعاناة من حالات تدهور ظروف العمل وتر اجع أوضاعه العامة.

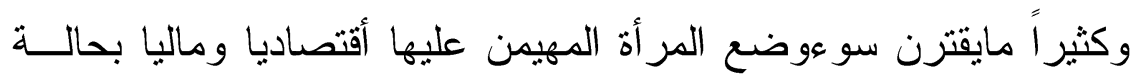
تمييز جنسى وهيمنة رمزية مزدوجة ومكررة تحيل إلى ماتلصقه بها التقافات من

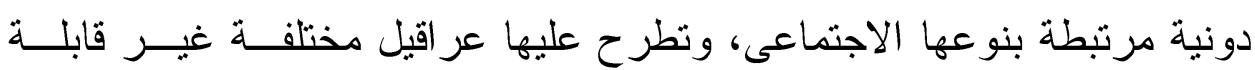

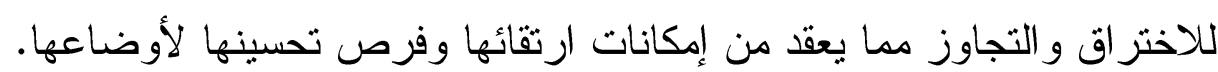

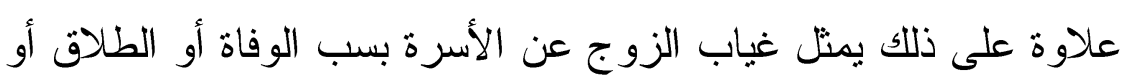

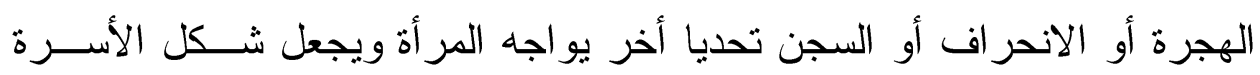
أحادياً و هذه الأسرة تكون ذات دخل واحد وترعاها في الغالب النساء أو الأمهات وهن أكثر عرضة إلى الفقر مما يضاعف من إعداد الفقراء من النساء بالمقارنة مع الرجال وفي هذه الحالة فإن عبء الأسرة ونتيجة لعدم وجود الأب و الــدخل

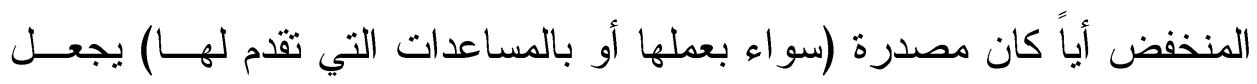

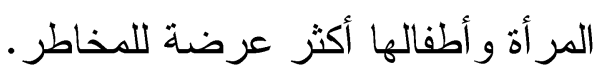
يساعد در اسة الفئات الفقيرة في المجتمع على تحديد علاقتهــا بمســتوى الخدمة ودرجة حاجة الإشباع بها وقدرة الخدمة ذاتها على فتح أبو ابها أو إغلاقها في وجه أبناء هذه الفئة حتى بوجود مفهوم العدالة الاجتماعية و الخدمات الإنسانية العامة.

ولقد حظيت قضايا المر أة ومشكلاتها بشكل عام و المر أة الفقيرة على وجه الخصوص باهتمام من جانب الحكومات ومنظمات المجتمع المدني على المستوى 
العالمي وسلط الضو ععلى تللك القضايا و المشكلات للكثف عن العوامل المتسببة فيها و إمكانية طرح الحلول العملية لتلافيها أو التقليل من حدنها. هنا تتمثل الحماية الاجتماعية للمر أة العاملة في الالتفات لحالتها الأسرية ودور ها الاجتماغي، ومر اعاة حالتها الأسرية ووضعها الاجتماعي.

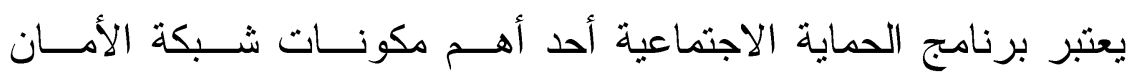
الاجتماعي التي تهدف إلى تحقيق تتمية اجتماعية شاملة و مستدامة مــن خــلال تطوير السياسات الاجتماعية بالتعاون مع الثركاء في القطاع الاجتماعي و ثقديم

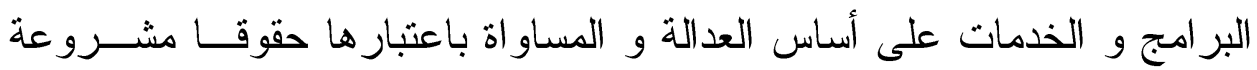
لكافة الفئات المهشة و الفقيرة. هنا يجب العمل على تحقيق الإدماج الاجتماعى للفئات المهيشة و الاشــــ فقراً وتحقيق الاستقرار و العدالة الاجتماعية والامن الاجتماعى لكل أفر ادالمجتمع دون تمييز بين الرجال و النساء وذلك من خلال استحداث شبكة حماية إجتماعية تتمكن فعليا من الحد من الفقر الذى يقف حائلا دون تحقيق التتمية ويؤدى إلـى تآكل الثروة البشرية ، ويشكل خطر ا على الاستقرار الاجتماعى و الاقتصــادى، حيث تؤثر شبكات الحماية الاجتماعية بشكل مباشر فى الجهود الرامية للحد من الفقر وتعزيز الرخاء عبر التحويلات النقدية أو العينية الموجهة لصالح الفئـات الفقيرة و الضعيفة وبشكل خاص النساء الفقير ات، كما تسهل لهذه الفئات الحصول على خدمات الرعاية الصحية و التعليمية .

\section{أولاً: مشكلة الدراسة:}

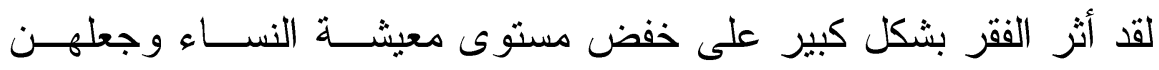

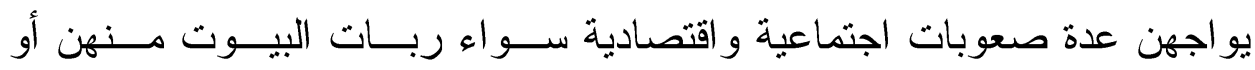
العاملات في أسواق العمل الحضرية أو العاملات بشكل هامشي في الريف، ومن تلك الصعوبات عدم قدرتهن على إعالة أنفسهن وتربية أطفالهن. 
تمنح معظم أنظمة الرعاية الاجتماعية في مصر ميزات للطبقـات العليــا و المتوسطة في المناطق الحضرية بينما تميز ضد الفئـات الفقبــرة و المهوشـــة، وتعتبر النساء الأكثر حرماناً ضمن هذه الفئات. تعيش أكثر مــن ثلـــث الأســر

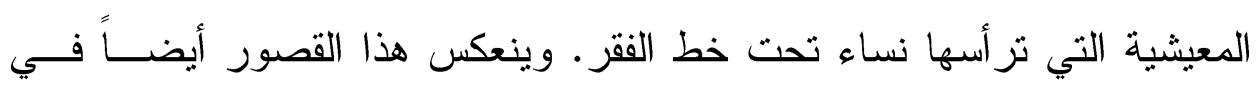
حقيقة أن فو ائد التأمين للأغنياء ونخب الدولة أكثر سخاء بكثير من تلـــك التـي ولـي للفقر اء. تحمي أنظمة الحماية الاجتماعية الفئات الأكثر ضــعفاً مــن الصـــمات و الضغوط طو ال حياتهز. إنها عادة ما تعالج مشاكل متعددة ومتر ابطة، بما فـي الـي ذلك الفقر و عدم المساو اة والأمن الغذائي. وتعتبر بر امج الحماية الاجتماعية أحد متطلبات مواجهة تهميش المــر أة ،

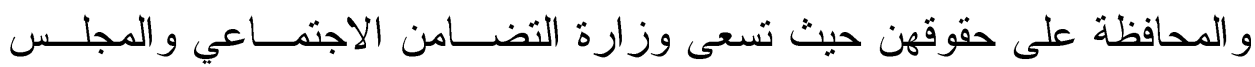

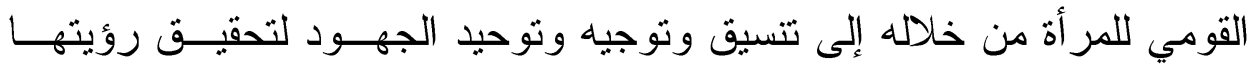
المتمنلة في تحقيق تتمية اجتماعية شاملة و مستدامة من خلال تطوير السياسات

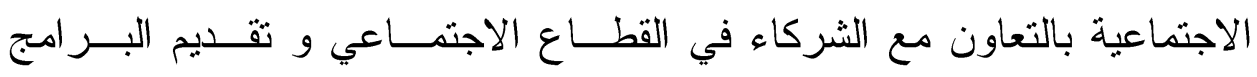
و الخدمات على أساس العدالة و المساو اة باعتبار ها حقوقا مشرو عة لكافة الفئـات المهششة و الفقيرة. تتداخل معدلات ارتفاع البطالة واتساع قاعدة الفقر و الفئـات

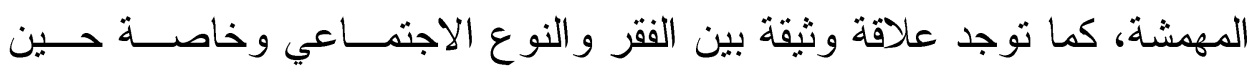
انكشاف محدودية قدرة النساء على الحصول على فرص منكافئة في العمل وفي الأجور و المناصب. يمثل الفقر القضية الاجتماعية الكبرى التي يو اجهها الإنسان و لايــز ال. إلا أن الفقر أصبح في الآونة الأخيرة ظاهرة عالمية نظرًا للتغيرات التي اجتاحت العالم في كافة النواحي الاقتصادية و الاجتماعية و التقافية نتيجة لسياسات العولمة

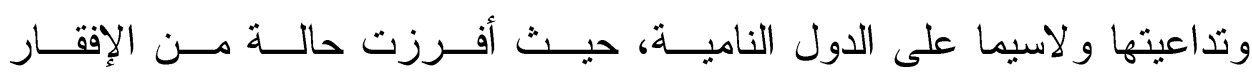
خاصة لفئات معينة من البشر و أهمها النساء. Povertization 


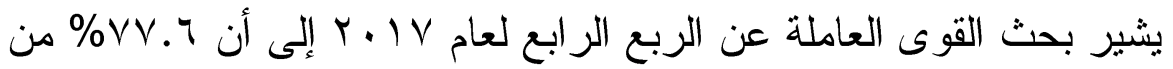

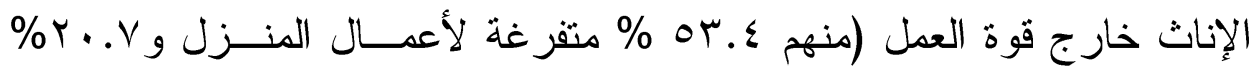

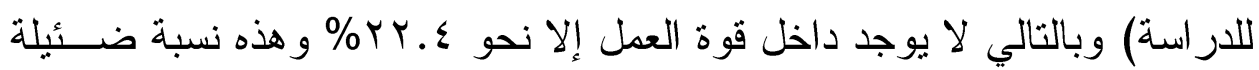

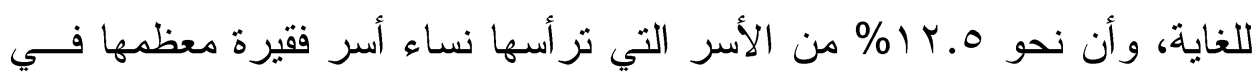

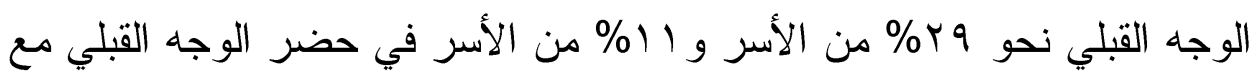

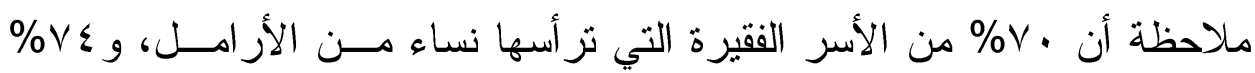

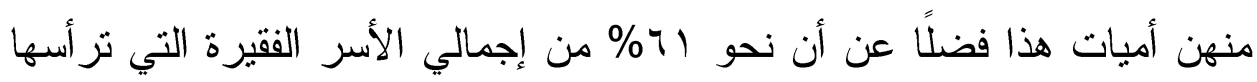

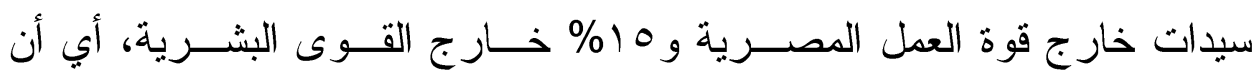

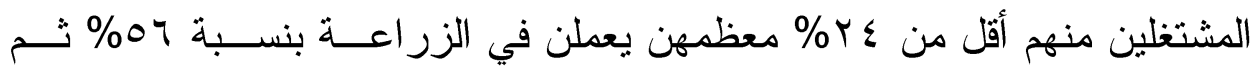

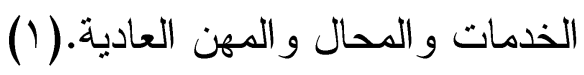
كما أن نسبة المر أة العاملة تحت خط الفقر ب.ب؟r\%، ونسبة مشاركة المرأة

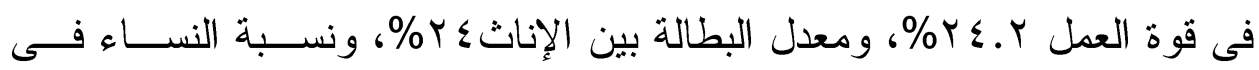

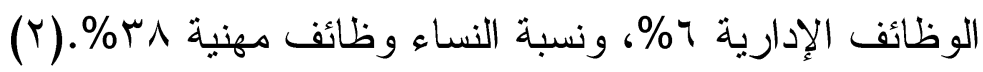

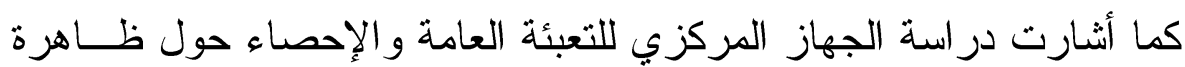

ممارسة العنف ضد المر أة على (r) - - -

( الجهاز المركزي للتعبئة العامة والإحصاء، نتائج بحث القوى العاملة للربع الرابع (أكتوبر -

$$
\text { د. IV ديسمبر) }
$$

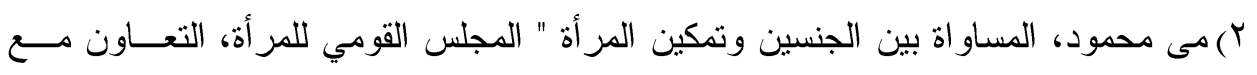

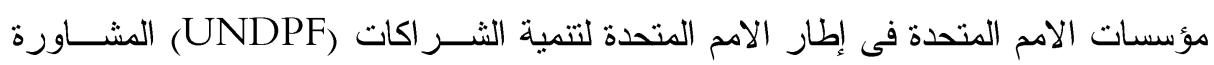

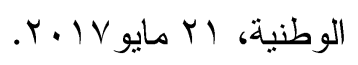

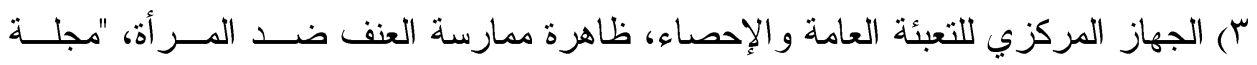

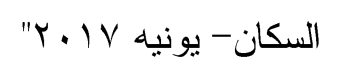




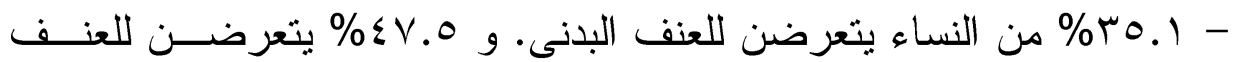
النفسى.

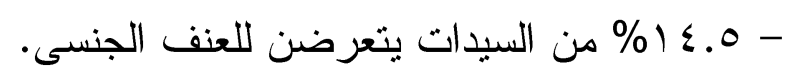
و أكدت دراسة بالمركز القومي للبحوث على أن بر امج الحماية الاجتماعية لا لانيل

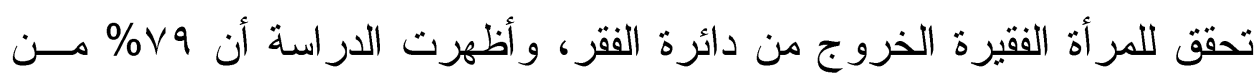
السيدات يلجأن إلي المؤسسات الصحية الحكومية من مستشفيات ومعاهد و عيادات لتلقي العلاج. فيما لا تتمكن ^ء؛ منهن من شراء الأدوية اللامة. (1)

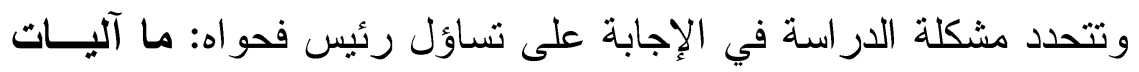

الحماية الاجتماعية للمر أة المصرية الفقيرة؟

\section{ثانياً: أهداف الدراسة:}

تهدف هذه الدر اسة إلى معرفة آليات الحماية الاجتماعية للمر أة المصرية الفقيرة

$$
\text { ا ـ التعرف على بر امج و أساليب حماية المر أة الفقيرة . }
$$

r. التعرف على مدى مناسبة تلك البر امج و الأساليب المقدمة للفقير ات.

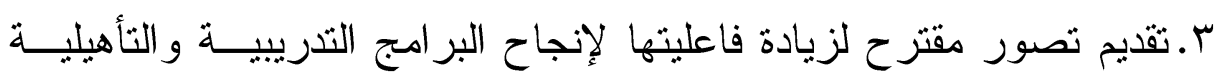
المقدمة لحماية المر أة الفقيرة.

\section{ثالثاً: تساؤلات الدراسة:}

تحاول الدراسة الإجابة على تساؤل رئيس فحو اه: ما آليـات الحمايــة الاجتماعية للمر أة المصرية الفقيرة؟ ا ـ ما بر امج وأساليب حماية المر أة الفقيرة .

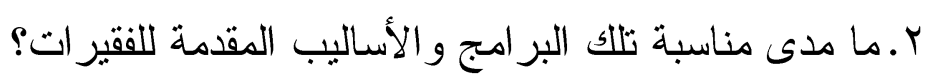
r. ما أساليب تطوير البر امج التدريبية و التأهيلية المقدمة لحماية المر أة الفقيرة؟

(1) المركز القومي للبحوث الاجتماعية والجنائية، الاحتياجات النوعية للمر أة المصرية الفقيرة، r.17. 


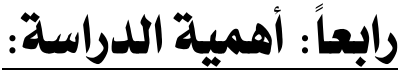

تتحدد أهمية الار اسة في جانبين:

أ) أهمية نظرية: وتتمثل في إثراء الدر اسات المتعلقة بحماية المـــرأة الفقبــرة ، و الأمان الاجتماعي.

ب) أهمية تطبيقية: حيث تكشف الدر اسة عن احتياجات و أوضاع المرأة الفقيرة ، وضعف الحماية الاجتماعية والاقتصادية للاولة، وتضع عدة توصيات لتفعيل

الحماية الاجتماعية للمر أة الفقيرة.

\section{خامساً: المدخل النظري للدراسة:}

يمثل المدخل النظري أهمية في توجيه البحث العلمي حيث يساعد الباحث على تفسير قضية الدر اسة ومعطيات الدر اسة الميدانية في ضوء رؤى المنظرين حول موضوع الدر اسة وتعتمد الدر اسة الحالية على: 1- 1 - نظرية ثُقافة الفقر:

يذكر لويس أن ثقافة الفقر يمكن أن تأتي إلى حيز الوجود في مجموعــة منتوعة من السياقات التاريخية. ومع ذللك، فإنها تنمو وتزدهر في المجتمعات مع مجموعة من الشروط أو جزء منها في اقتصاد مالي منهك و إنتاج من أجل الربح فقط، ومعدل عال من البطالة و واستخدام قليل للعمال غيــر المهــرة، ومســتوى منخفض من الأجور، و الفشل في توفير منظمات اجتماعية سياسية واقتصــادية على المستويين التطوعي و الحكومي، وتر اكم الثروة عند فئة محددة ( (') وتوجد ثقافة الفقر أكثر ما توجد في المناطق المتخلفة، التي تتميز بارتفاع معدل درجة التزاحم في المسكن و عدم تو افر الخلوة الاجتماعية، وشيوع العلاقات المباشرة، وتتصف المناطق المتخلفة الر اعية لتقافة الفقر بحد أدنى من التتظــيم يصل إلى مستوى الأسرة النووية، بالإضافة إلى وجود جماعات مؤقتـــة غيــر

1) Coward, B. E.; Feagin, J. R. and Williams, Jr. J. A. (1973). The Culture of Poverty Debate: Some Additional Data, Social Problems, 21(5): 621-634. 
رسمية، ويعتبر وجود مثل هذه الجماعات مؤشراً على وجود مستوى أدني مــن التنظيم، مما يعطي لثقافة الفقر صفتها الهامشية في المجتمع الأكبر الذي يتميـز فيز

بدرجة كبيرة من التعقيد و التخصص و التتظيم(')

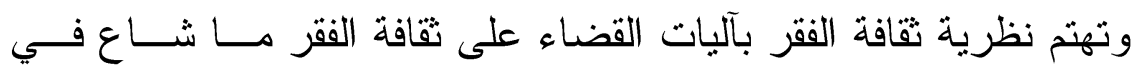

العقود الأخيرة من القرن الماضي من وجود سكان من ذوي الدخل المرتفع فـي مساكن ذوي الدخل المختلط، الذي يدفع الأسر الأخرى لتبني سلوكيات مقبولـــة وبناءة من الناحية الاجتماعية، منها السعي لإيجاد عمل منتظم واحترام الملكيات

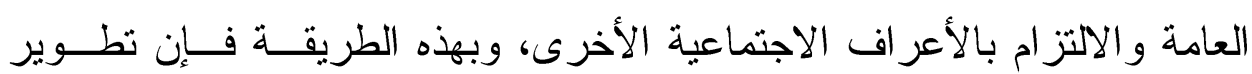
مساكن الدخل المختلط هو استجابة سياسية لمفهوم تقافة الفقر - الذي خضع لنقاش ساخن - وهذا المفهوم هو النظرية القائلة أن أحد العوامل الأساسية لوجود الفقر هو العادات غير الاجتماعية الهدامة التي تعود عليها الكثير من الأسر ذات الاخل

(Y) المنخفض، و التي تعد عقبة في طريق رفاهيتهم و انتقالهم إلى الطبقات العليا حيث عرف "اوسكار لويس " ثقافة الفقر بانها طريقة لحياه تتتقل من جيل الى جيل و تزود الافر اد بأسلوب مميز للمعيشة، ويمكن وصف ثقافة الفقر من خلال

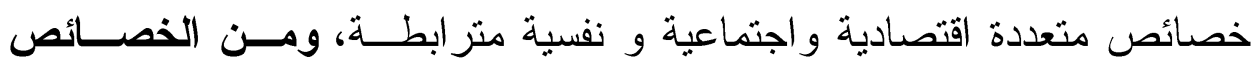

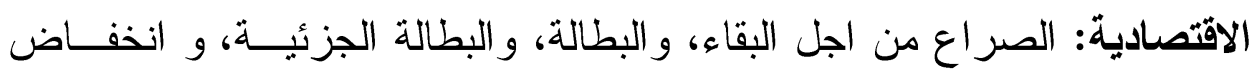

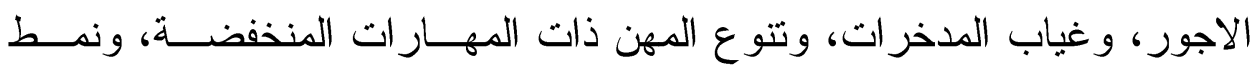
الشر اء المستمر للطعام بكميات قليلة كلما دعت الضرورة الى ذلك، واســتـعمال الاثاث و الملابس المستعملة، وشيوع التسليف المنظم بين الجيران، و الاقتــر اض

1) Gajdosikienë, I. (2004). Oscar Lewis' Culture of Poverty Critique and Further Developmen, Sociologija. Mintis ir veiksmas, ISSN 1, 13923358.

2) Kasarda, J. D. (1990). City jobs and residents on a collision course: The urban underclass dilemma, Economic Development Quarterly, 4(4): 313-319. 
بفو ائد مرتفعة، وغياب المخزون السلعى من الطعام فى المنزل، امـا الخصــائص

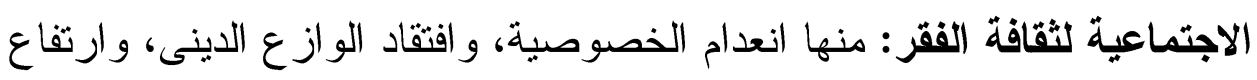
معدلات الوفاة ، و كثرة هجر الزوجة و الاو لاد، و الشعور بالاستسلام و القدرية .

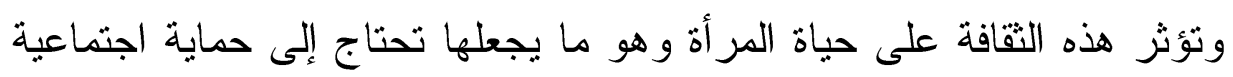

لمواجهة الضغوط الحياتية المتعددة. وينظر علماء الاجتماع إلى الفقر على أنه مشكلة اجنماعية تحول بـين الإنسان وتحقيق المستوى الاقتصادي و الاجتماعي المرغوب به حيث إنه فـى مجمله يوضح عدم قدرة فئة نحو تحقيق حاجاتهم نتيجة لتعقد البناء الاجتماعي، فهو حالة من الحرمان من الحياة اللائقة التى يتطلع الفرد أو المجتمع الى التمتع بها و الفقر لا يعنى الافتقار إلى ما هو ضروري لتحقيق الرفاهية المادية للفــرد ولكنة يعنى أيضا الحرمان من الفرص و الاختيار ات الاساسية من خوض حيــاة صحية، و الحصول على دخل لائق و التمتع بالكر امة و الاحتر ام وهو ما يشير إلى هلى أن الدخل إحدى الاختبار ات التى برغب الافر اد بالتمتع بها (') . r- تفسير ات أخرى للافقر : يرى جيدنز أن الناس في كثير من أنحاء العالم يتضورون جوعا، ليس

لأخطاء ارتكبو ها بل لأنهم يعيشون في أوضاع يسودها فقر مدقع. (Y)

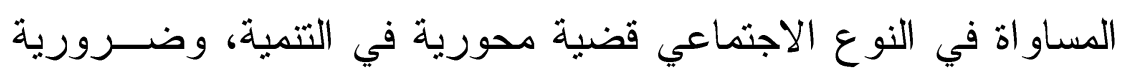
للقضاء نهائيًا وفعليًا على الفقر وهو ما تشير إليه استر اتيجية البنك الدولي.

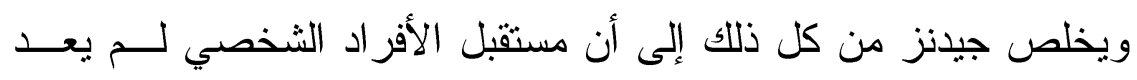

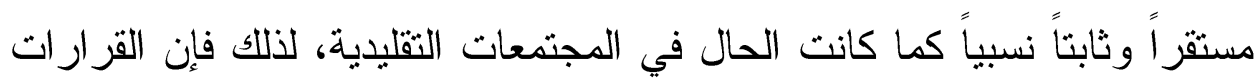

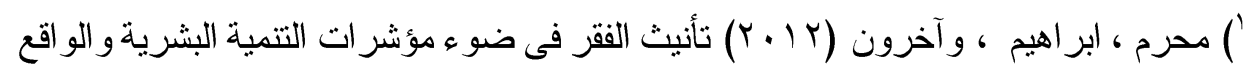

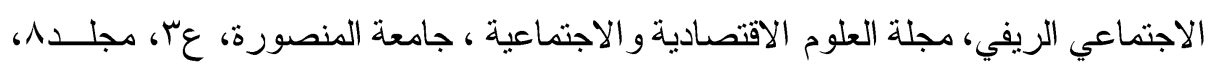

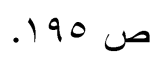

2) Giddens , Anthony (1999) Runaway World : How Globalization is Reshaping our Lives, London, Profile Books , p -3 
مهما كان نوعها واتجاهها، أصبحت تتطوي الآن على واحد أو أكثر من عناصر المخاطرة بالنسبة إلى الأفر اد.

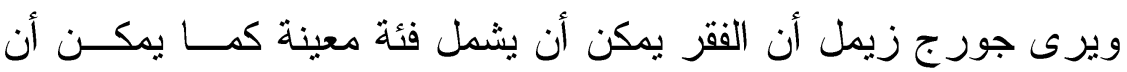

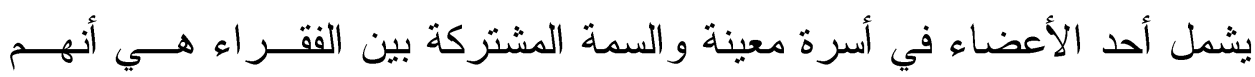
يتلقون المساعدة سواء من طرف ولي أمرهم أو أقاربهم أو الدولة اي يحضون بالدعم و المساعدة و الإعانة من طرف الجماعات التي ينتمون اليها و المجتمع الذي يوجدون فيه.

أما (جيلين فيرى) فقال إن الفقر حالة معيشية لا يستطيع الفرد في ظلهــا الحفاظ على مستوى لائق للمعيشة يوفر لله القوة و القدرة المادية ويهيئ له ولمــن لهن يعولهم التكييف الاجتماعي المطلوب.

\section{سادساً: الدراسات السابقة:}

يعرض الباحث لبعض الدراسات السابقة التي ترتبط بموضوع الدراســـة

وفق ما يسمح به المجال، وذللك بما يبرز مدى تناول هذا الموضـــوع ، وكيفيــة تتاوله ، و الأبعاد التي تحتاج إلى مزيد من الدراسة. وتتمثل هذه الدر اسات في:

( ) المناور، فيصل حمد(1/.r) واقع المخاطر الاجتماعية في الدول العربية (1)

تهدف هذه الدراسة إلى تسليط الضوء على أوضاع المصادر الاجتماعية

في الدول العربية، و الكشف عن أهم التذاعيات المترتبة عليها، وقد قسمت إلـى إلى الـى قسمين يسبقهما مقدمة ويليهما خاتمة؛ ناقش القسم الأول السياق النظري للمخاطر الاجتماعية، من خلال التركيز على الاعتبارات التي تحدد أهمية تتاول المخاطر الاجتماعية، وتفسير مفهوم المخاطر الاجتماعية و أبعاده. وتتاول القسم الثاني من

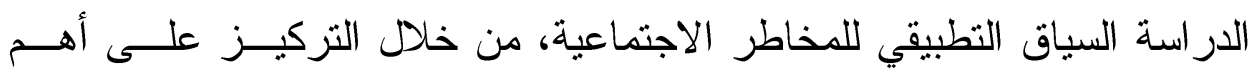
المخاطر الاجتماعية البارزة في الدول العربية. توصلت هذه الدراسة إلى عـدة

() المناور، فيصل حمد(1 ( †) و اقع المخاطر الاجتماعية فى الدول العربية، جامعة الكويت،

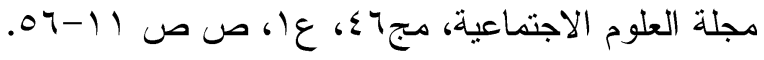


نتائج، كان أهمها أن المخاطر الاجتماعية التي تعاني منها الدول العربية "كتفشي ظاهرة الفقر، ارتفاع معدلات البطالة، انتشار العشوائيات، اختلالات و اضحة في البناء الأسري، و غير ها". ما هي إلا نتيجة لضعف أداء شبكات الأمان الاجتماعي

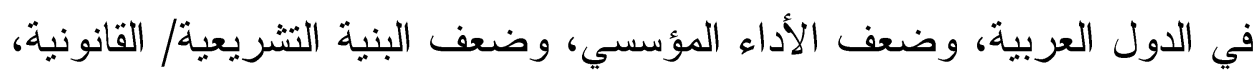

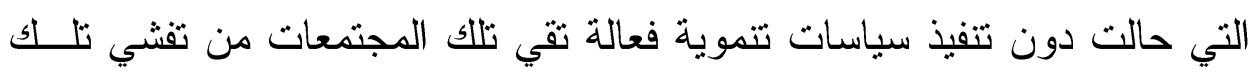
المخاطر .

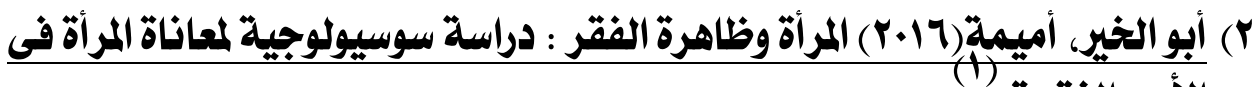 الأسر الفقيرة.}

من المشكلات المهمة و الخطيرة الجديرة بالبحث و التحليل نظر التطـــور

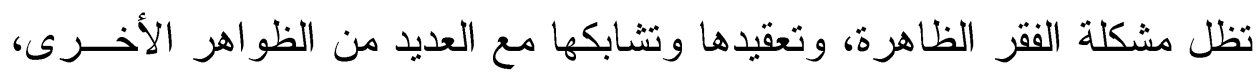
وزيادة نسب من يعاني منها، بالرغم من جميع الجهود المبذولــة علــى جمبــع

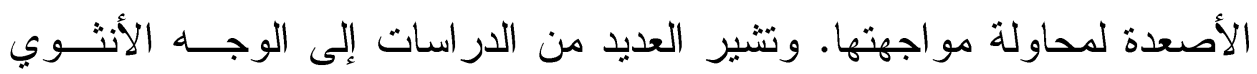

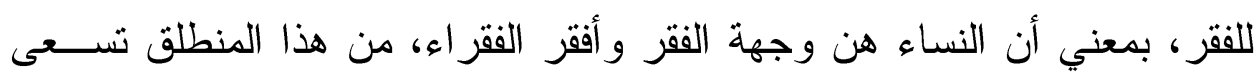

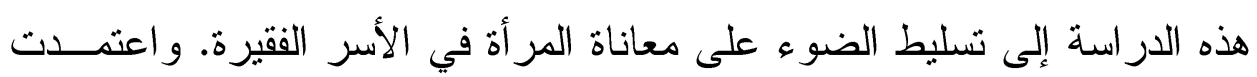

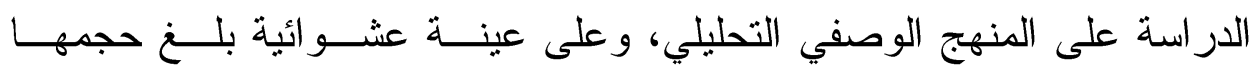

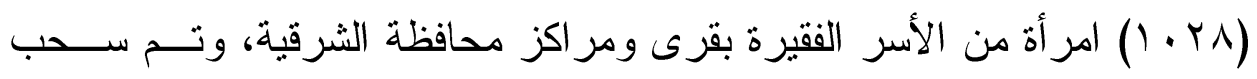
العينة بمعرفة وحدة الإحصاء بالمركز القومي للبحوث الاجتماعيــة والجنائيــة

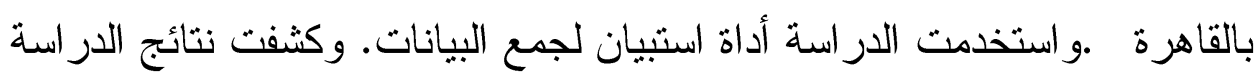

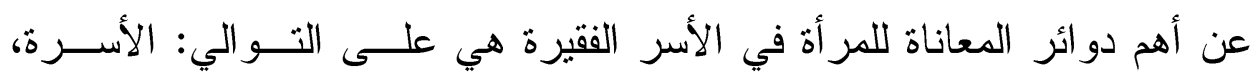

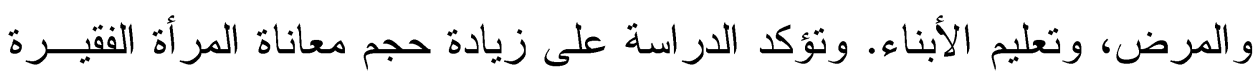
بعد تطبيق الدولة لسياسات التكيف الهيكلي (الخصخصة)، و انسحاب الدولة مـنـ

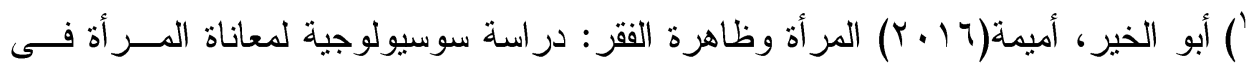

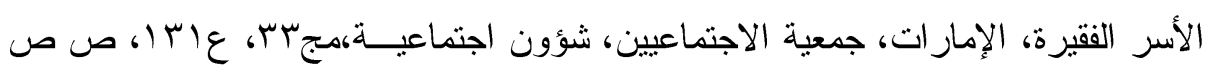


مجال الرعاية الاجتماعية، وتحديدا من مجالي الصحة و التعليم. فتجــــ النســـاء يسعين بشتى السبل لسد هذا العجز.ومن أهم النتائج التي توصلت إليها الدراســـة

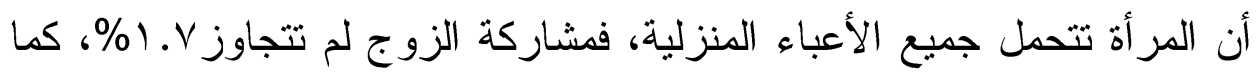

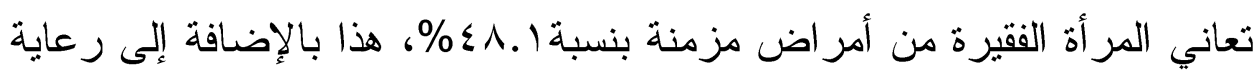

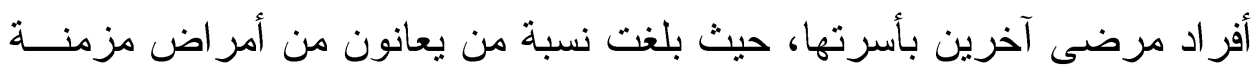

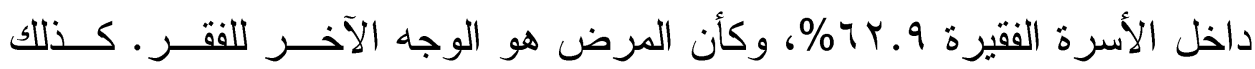

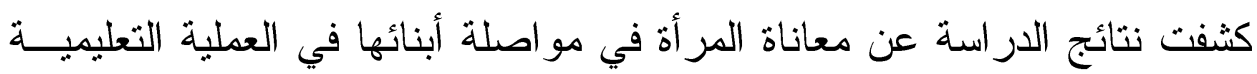

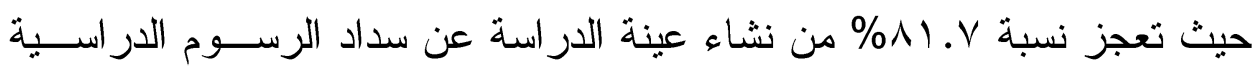
لأبنائهن.

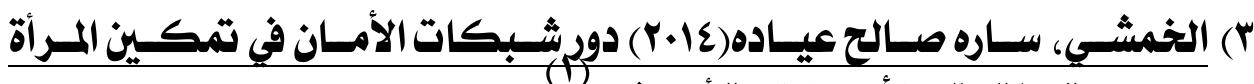

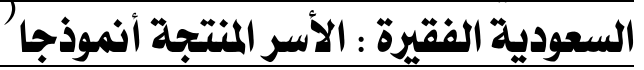

هدف البحث إلى الكشف عن دور شبكات الأمان الاجنماعي في تمكـين المر أة السعودية الفقيرة "الأسر المنتجة أنموذجا". وتكمن أهمية البحث في زيــادة اسهام القوى العاملة الوطنية النسائية في القطاعات التتموية والاهتمام بتأهيلهـــا وتدريبها؛ لتحسين إنتاجيتها ورفع كفاءة أدائها و الاستمرار في إحــلال العمالـــة الوطنية محل الو افدة. وأستخدم البحث منهج المسح الإجتماعى الشامل. وتكونت

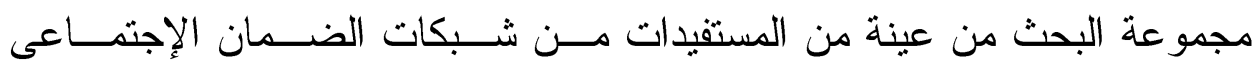
الحكومي المتمثلة في مكتب الضمان الاجتماعي بمدينة الرياض . وتمثلت أدوات

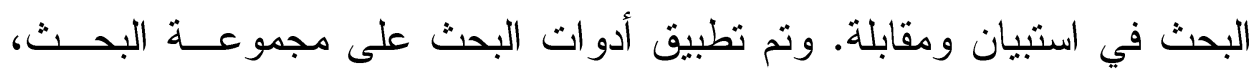
وتوصلت النتائج إلى وجود العديد من المعوقات الإدارية و التمويلية و التســـويقية؛ فالإجر اءات الإدارية تتطلب العديد من التصاريح حسب نشاط المشروع سواء في

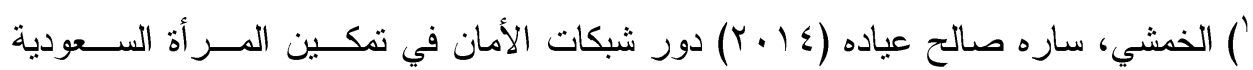

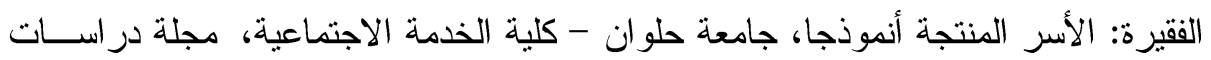

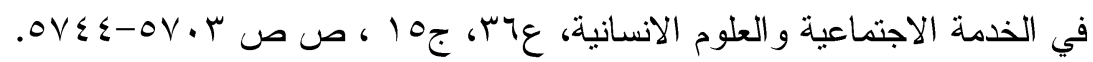


الأمانة أو من الفرقة التجارية، بالإضـافة إلى العديد من الثروط وخاصـــة فيمــــا

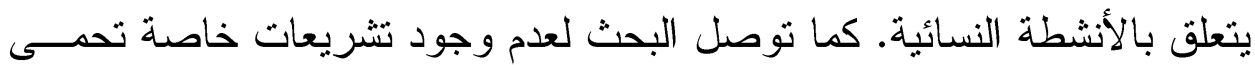
أصحاب مشروعات الأسر المنتجة؛ لحماية حقوقهم مــن المعوقـات، وأن مــن المعوقات الاعتماد على الباز ارات و المعارض وهى فتر ات موســـية لا تــؤمن الاخل الثابت و الاستقر ار .

(1) ع) بنيني، أحمد (rا.r) الحماية الدولية والوطنية للمرأة ضد العنف، الجزائر

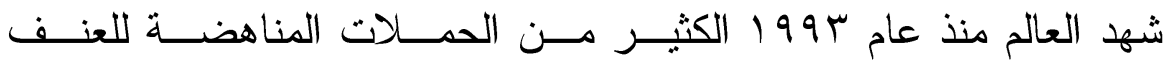

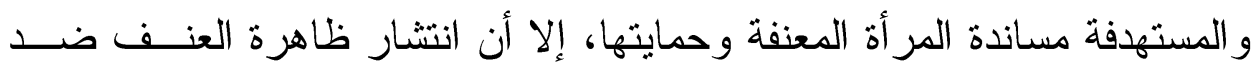
المر أة وتوسع أثار ها جعل من محاربتها ضرورة حتمية، من خلال توفير أرضية

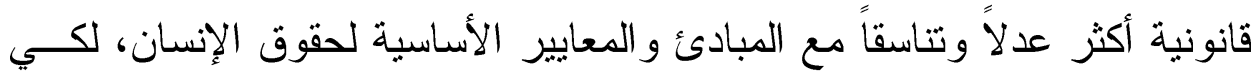

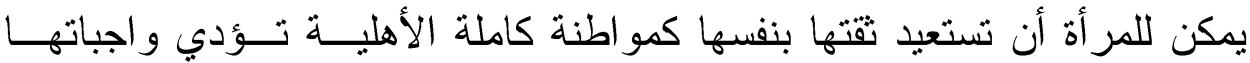
المفترضة، وتتال حقوق كاملة غير منقوصة. ورغم الاهنمام البــالغ للمشــرع الاستوري الجزائري بالمر أة من خلال تخصيصه لها أحكام عديدة ســواء فـي

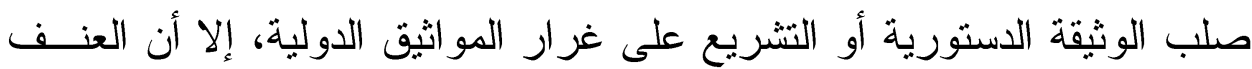

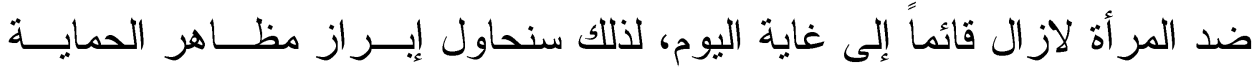
الدولية و الوطنية للمر أة ضد العنف بمختلف أشكاله.

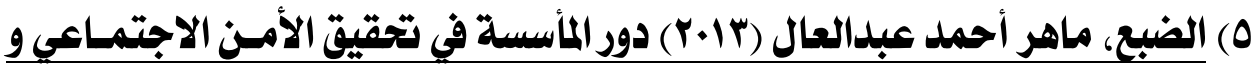

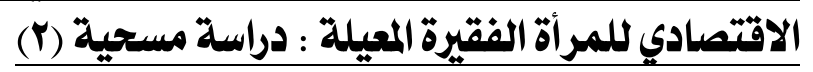

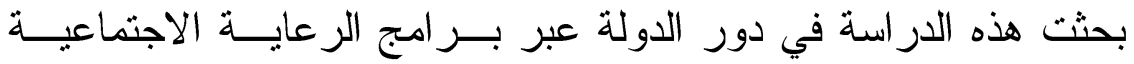

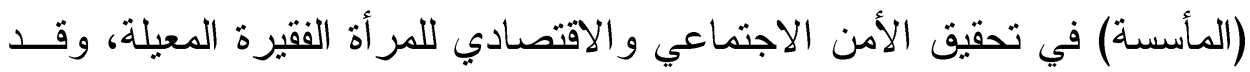

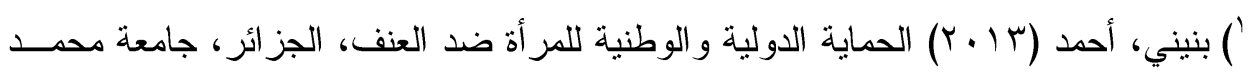

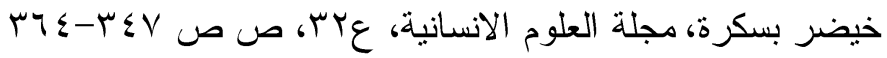

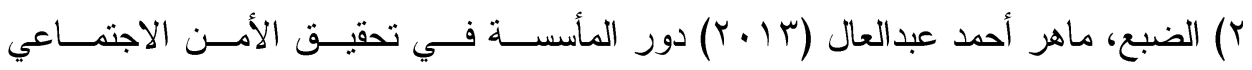

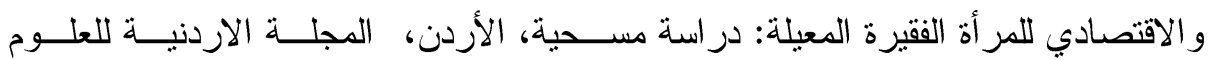

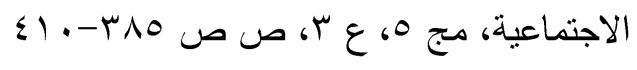


استخدم الباحث منهج المسح الاجتماعي الثامل، حيث قــام بتطبيــق الدراســة

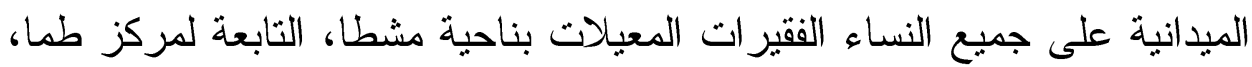

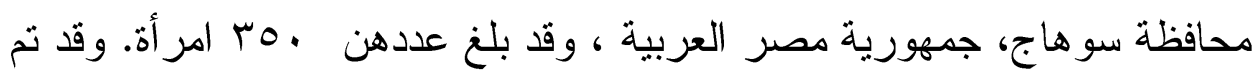

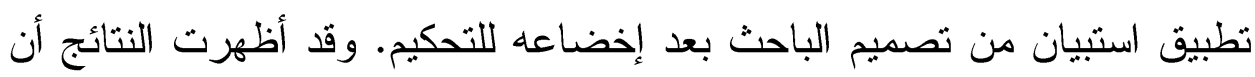

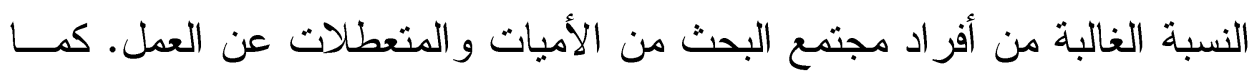

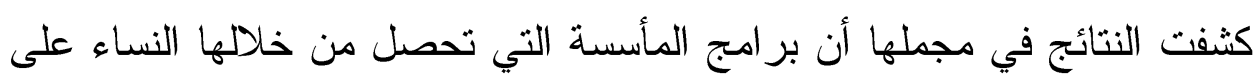

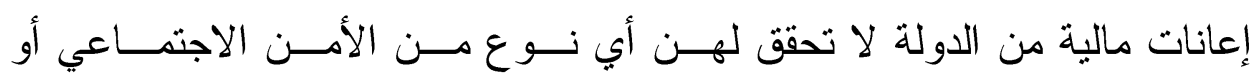

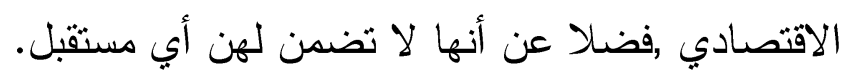

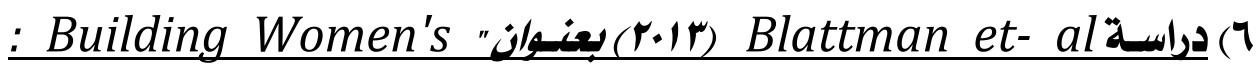
Economic and Social Empowerment Thruogh "Enterprise "Uganda

قام الباحثون بدر اسة اثار منح المرأة وخاصة المر أة الفقيرة في أوغنــــا منح مالية وتدريب حول المهار ات الاساسية على تحقيق النمكـين الاقتصــادي للمر أة من خلال تصميم وتنفيذ بر امج معده لهذا الغرض صممت من قبل منظمة ايطالية غير حكومبة.

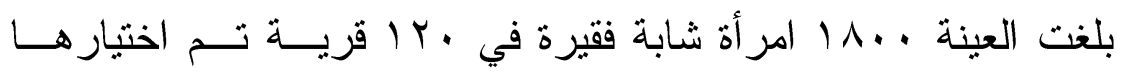

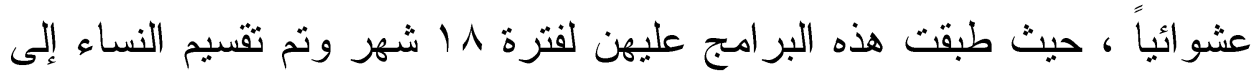

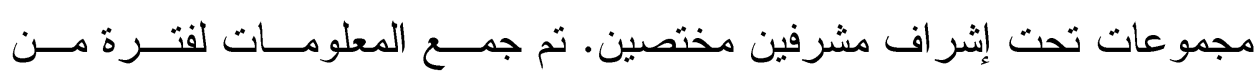

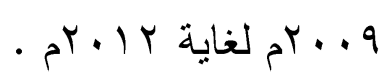

خلصت الدراسة إلى إن المرأة الفقيرة تمكنت من الحصول على منــافع

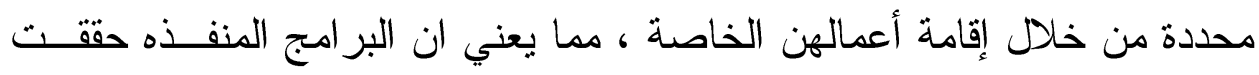
قيمة أعلى من كلفتها وبشكل عام فإن الدراسة خلصت إلى إن التمكين الاقتصادي للمر أة يمكن ان يحقق لها اثار ايجابية خاصةً في المجال الصحي.

1) Blattman, Christopher, Green, Eric, Annan, Jeannie and Jamison, Julian (2013): Building Women's Economic and Social Empowerment Thruogh Enterprise "Uganda, https://www.poverty-action.org/.../wings 


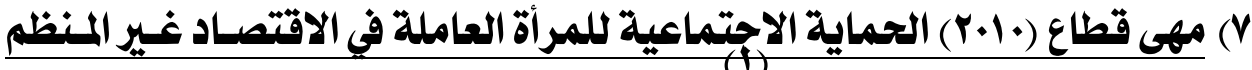

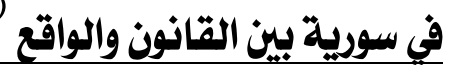

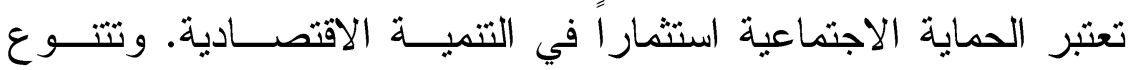
احتياجات الحماية الاجتماعية للعمال وتتفاوت حسب المناطق، و هذا يتوقف على الى الت توفر الخدمات وتمكين العمال من الوصول إليهما. ففي حين أن الخدمات الصحية في بعض المناطق الريفية مفتقدة إلى حد بعيد، فإن التأمين الصحي سيكون مــن

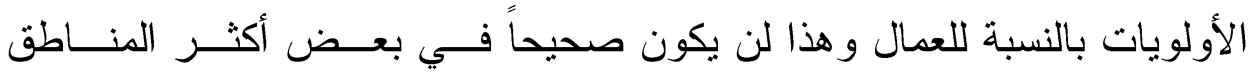
الحضرية، حيث الخدمات الصحية المجانية متاحة.

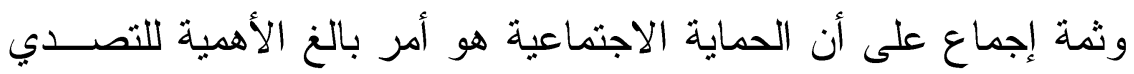

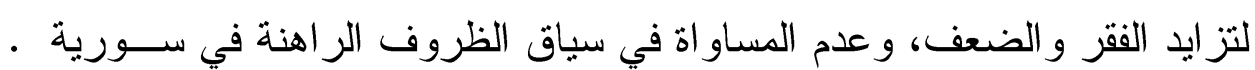
وتتراوح ضمانات الحماية الاجتماعية بين برامج التأمين الاجتمــاعي الثــامل وتوفير الخدمات الاجتماعية الأساسية (الصحة والتعليم) و المساعدة الاجتماعبــة

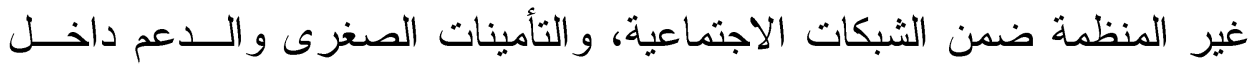
الأسرة. استتاداً للقو انين والأنظمة السورية، فإن أصحاب العمل مطالبون بتقــديم مساهمات لمؤسسات التأمينات الاجتماعية للعاملين لديهم لتغطية إصـابات العهـلـل

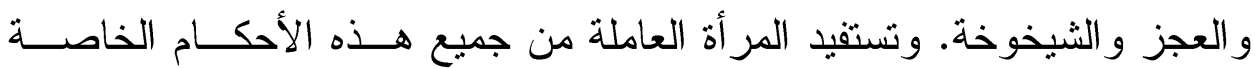
بالحصول على (إجازات إدارية، إجاز ات مرضية، و التدريب، و الأمومة المدفوعة الأجر لأول ثلاثة أطفال فقط).

\section{موقف الدراسة الحالية من الدراسات السابقة:}

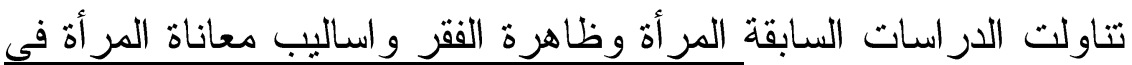
الأسر الفقيرة، وعرضت لدور شبكات الأمان في تمكين المر أة الفقيرة من خلال الأسر المنتجة ، كما اهتمث بالحماية الدولية و الوطنية للمر أة ضد العنف، ودور

') مهى قطاع (• ( + ) الحماية الاجتماعية للمر أة العاملة في الاقتصاد غير المنظم في سورية

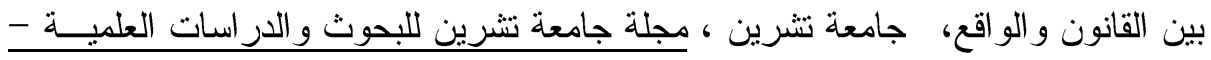

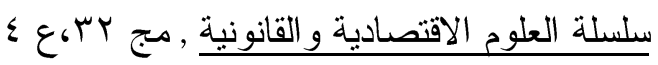


المأسسة في تحقيق الأمن الاجتماعي و الاقتصـــادي للمــر أة الفقةــرة المعيلــة، وتتاولت الحماية الاجتماعية للمر أة العاملة في الاقتصاد غير المــنظم ، فعاليــة برنامج مقترح لتتمية الوعي بالصحة الإنجابية لدى الطلاب. واستفادت الار اسة الحالية من الاراسات السابقة في: - - تحديد موضوع و أبعاد الدر اسة الحالية. - ت تحديد ومحاور أداة الدر اسة. - - تحديد منهج الدراسة.

وتميزت الدر اسة الحالية في دراسة المر أة الفقيرة في المجنمع المصري، و أساليب الحماية من الفقر و العنف و المشكلات الصحية ، وذلك من خلال عـدد من المؤسسات تمثلت في وزارة التضامن الاجتماعي، و المجلس القومي للمــر أة، و الجمعيات الأهلية. حيث تعني هذه المؤسسات بتقديم بر امج لمســـاعدة وحمايـــة

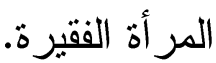

\section{سابعاً: مفاهيم الدراسة:} 1) مفهوم الحماية الاجتماعية:Social protection

تعبر الحماية الاجتماعية عن مجموعة من السياسات و البرامج الراميــة إلى الحد من الفقر من خلال تعزيز كفاءة أسواق العمل و الذى يقلل من تعــرض مـ المجتمعات للمخاطر وتعزيز قدرة المجتمعات على حماية أنفسهم ضد المخــاطر

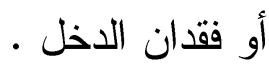

وتتكون الحماية الاجتماعية من عناصر رئيسية هى أســواق العمـلـل ،

التأمين الاجتماعى ، المساعدة الاجتماعية ، استتاداً المخططات حماية المجتمعات المحلية وحماية الطفل ، وتعد نظم الحماية الاجتماعية بمثابةآليات مؤسسية تساعد الافر اد على إدارة المخاطر الاجتماعية أو التخفيف من أثار ها بمجرد وقوعها ـ وتعرف الحماية الاجتماعية بإنها تلك البرامج والسياسات التى تهدف إلى الحـــ من الفقر و المخاطر التى قد يتعرض لها الافراد غير القادرين على العمل بسبب 
المرض أو كبر السن وكذلك حماية السكان منالتقلبات الثديدة وغير المتوقعة فى مستوى المعيشة نتيجة التغير ات الاقتصادية المختلفة( (1) . و الحماية الاجتماعية، كما عرفها معهد الأمم المتحـــدة لبحـــوث التتميــة الاجتماعبة، تهنم بمنع و إدارة و التغلب على الحالات التي تؤثر سلبًا على رفاهـــة

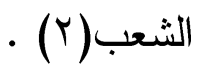

ومن ثم فالحماية الاجتماعية هي مجموعة الآليات و السياسات و البـــر امج

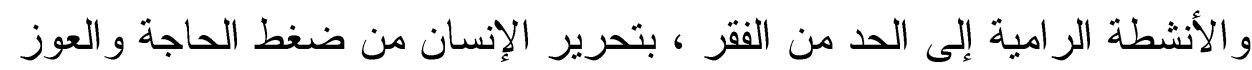
و الحرمان ، و الحد من خسائره وحمايته مما يهدده من أخطار داخلية وخارجية.

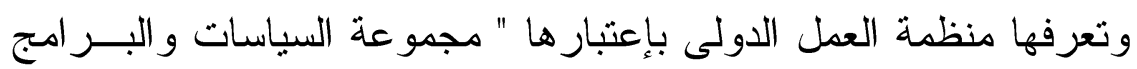

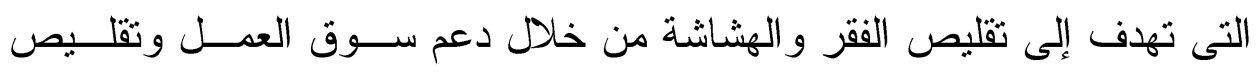
تعرض الافر اد للمخاطر وتعزيز قدرتهم على حماية أنفسهر من احتمالات فقدان

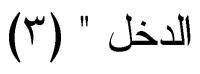
وتتمثل الحماية الاجتماعيةإجر ائياً في عدة مؤشرات تثمثل فــي:" ثقـديم

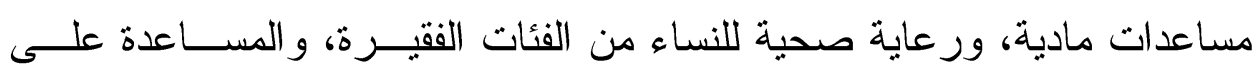
التدريب والتأهيل لسوق العمل، إضافة إلى توفير فرص عمل، ووجود إجراءات ودئ لحماية المر أة من العنف" لهيت : الفقر

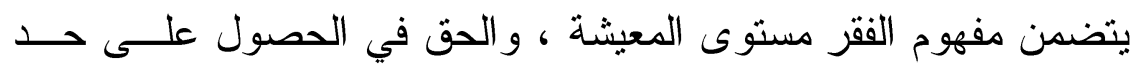
أدنى من الموارد. ومستوى المعيشة بمكن التعبير عنه بالاستهلاك لسلع محددة ، () الرشيدى، عبد الونيس محمد ، (10 • ץ)، سياسات الحماية الاجتماعية و الحد مــن مشـكلة

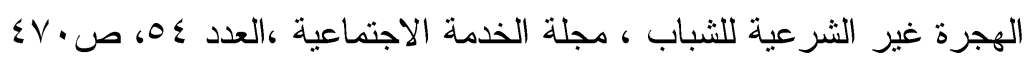

2) United Nations Research Institute for Social Development (UNRISD). (2010). Combating Poverty and Inequality: Structural Change, Social Policy and Politics.

r) حسن ، محمد حسين صادق ، ( (1) الحماية الاجتماعية كمؤشر لإثــباع الحاجـات

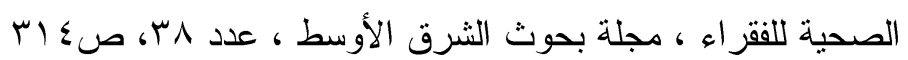


مثل الغذاء و الملابس أو السكن، التي تمثل الحاجات الأساسية للإنسان التي تسمح

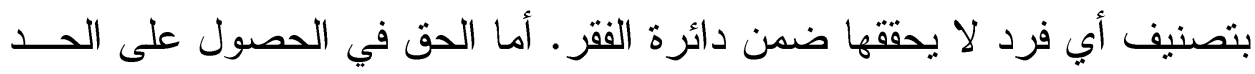

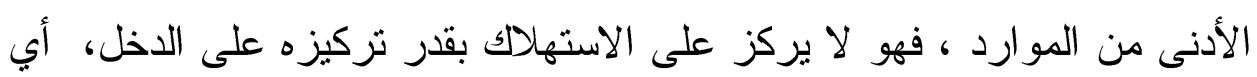

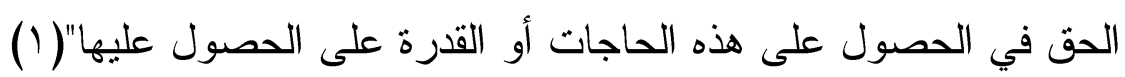
-وفي تقرير التتمية البشرية لعام ع . . بم ركز في وصفه للفقر Poverty على

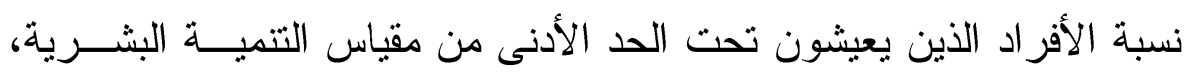

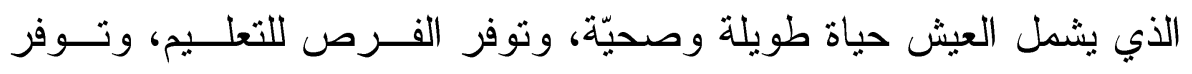
معايير ملائمة للحياة الكريمة، بالإضافة إلى مستويات الدخل المتدنية.(ب) ويمكن تحديد الفقر إجرائياً في عدة مؤشرات هى: - عدم القدرة على تحقيق الحد الأدنى من مستوى المعيشة المرغوب اجتماعياً - الحرمان المادي المتمثل في انخفاض استهلاك الغذاء كماً ونوعاً. - تدني الحالة الصحية و المستوى التحليمي و الوضع السكني. - الحرمان من تملك بعض السلع والأصول المادية الأخرى. - عدم القدرة على مواجهة الحالات الصعــبة كالمرض و الإعــاقة و البـــالة و الأزمات.

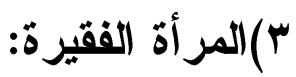

يمكن تعريفها بأنها المرأة التي تعاني حالة من الحرمان المادي تتجلــى أهم مظاهرة في انخفاض استهلاك الغذاء كماً ونوعاً وتـدني الحالـــة الصــــية و المستوى التعليمي و الوضع السكني و الحرمان من تملك بعض السلع و الأصول

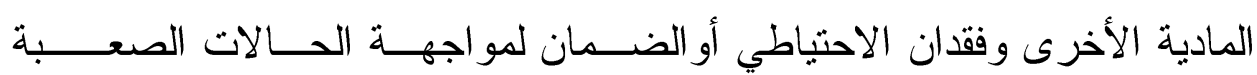

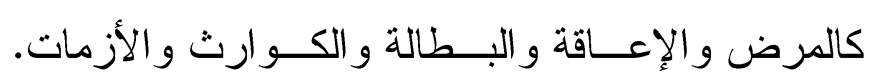

() عبد الرزاق الفارس( ( . ب) الفقز وتوزيع الدخل في الوطن العربــي، مركـز دراســات

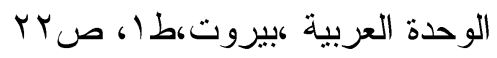

2) UNDP ,Human development report 2004,p87. 
وتأخذ ظاهرة الفقر أبعاد عديدة يمكن التطرق إلى بعدين أساسيين هما فقر

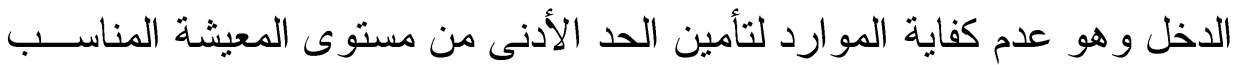
اجتماعيا والبعد الأخر هو فقر القدرة أى تدنى مستوى قدر ات الفرد إلى حد يمنعه

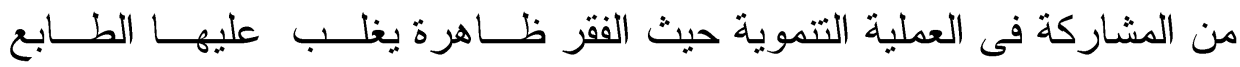

(النسائي(') من (1)

تعتبر النساء في المنطقة العربية أفقر من الرجال عندما ينظر للفقر على أساس مفهوم القدرات الإنسانية والتي تعتبر من المؤشرات الهامة لفقــر المــر أة حسب تقارير الأمم المتحدة، سواء المتعلق بتلك المؤشرات من النواحي الصحية أو التعليمية أو الاجتماعية أو الاقتصادية أو الثقافية.

\section{ثامناً: الإجرايوات المنهجية للدراسة:}

أ- منهج الدراسة: اعتمدت هذه الدراسة بشكل أساسي علـى مــنهـ المســح

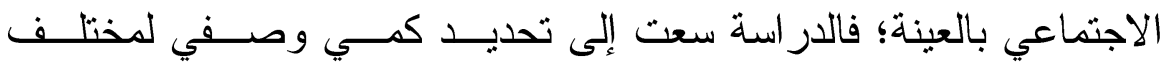

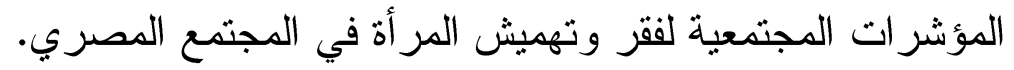

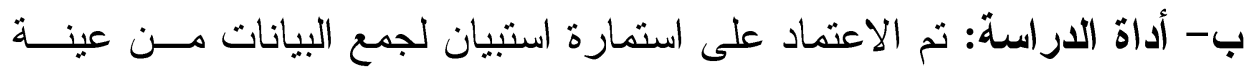
الدر اسة، حول أثكال المعاناة وأساليب الحماية الاجتماعية. ج- مجالات الار اسة:

- المجال البشري: تم تطبيق الدراسة الميدانية على المر أة الفقيرة من الفئـات العمرية و التعليمية المختلفة.

- المجال المكاني للار اسةة: طبقت الدراسة المبدانية في مركز بنها بمحافظـــة القليوبية.

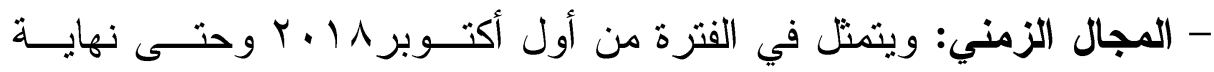
ديسمبر من نفس العام.

دـ-عينة الارراسة: تم سحب العينة من النساء الفقبر ات المثرددات على الوحدات الاجتماعية، و المجلس القومي للمر أة، وقد تم سحب مفردات العينة بطريقــة

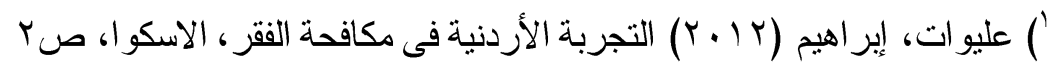


عشوائية منتظمة من كشوف المترددات على هذه الوحدات بغرض الاستفادة أو الحصول على الرعاية الاجتماعية وتمثلت العينة في ـ 10 مفردة. - أسلوب اختيار العينة: بتمثل أسلوب اختبار العينة من كثوف المتــرددات بطريقة عشو ائية منتظمة في الفترة من أول أكتوبر وحتى نهايــة ديســمبر

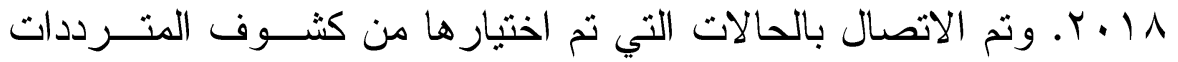
ومقابلتهن في منازلهن، وذلك بعيداً عن الوحدات التي تقدم لهن الخدمة حتى دهن لاتتأثر إجابتهن بالعاملين في الجهات التي تقدم الخدمة. وتمثلت مبررات اختيار عينة الاراسة في: - النساء الفقير ات اللاتي يتعرضن لعنف.

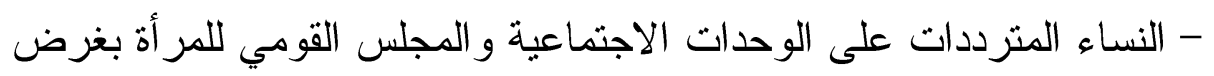

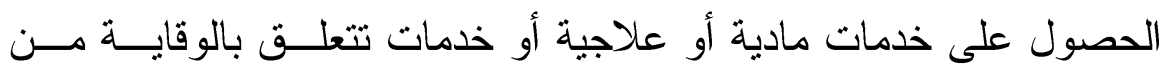
العنف. هـ - طريقة التحليل الإحصائي: اعتمد الباحث على برنــامج spss لتحليـلـ البيانات.

\section{تاسعاً: نتائج الدراسة الميلانية:}

(البيانات الأسـاسية:

\begin{tabular}{|c|c|c|}
\hline$\%$ & פ & الفئة العمرية \\
\hline$Y \varepsilon . V$ & rv & أقل من · س سنة \\
\hline r.r & 07 & $\varepsilon \cdot-\mu$. \\
\hline TY.V & $r \leq$ & $0 .-\varepsilon$. \\
\hline $1 \varepsilon \ldots$ & Y & ، م سنة فأكثر \\
\hline $1 \ldots$ & 10. & المجموع \\
\hline
\end{tabular}


فيما يتعلق بالعمر تشير البيانات الميدانية الى ارتفاع نسبة من تتــراوح

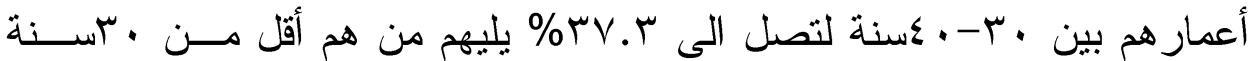

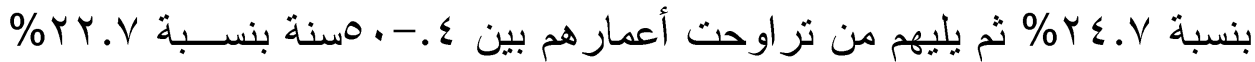

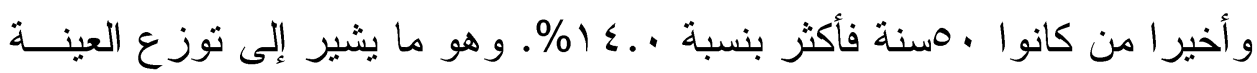
على الفئات العمرية المختلفة، وتتركز غالبية العينة في الفئة العمرية التي تقـلـل عن ·عسنة، وهى الفئة الأكثر قدرة على العمل. شكل(1) (1)

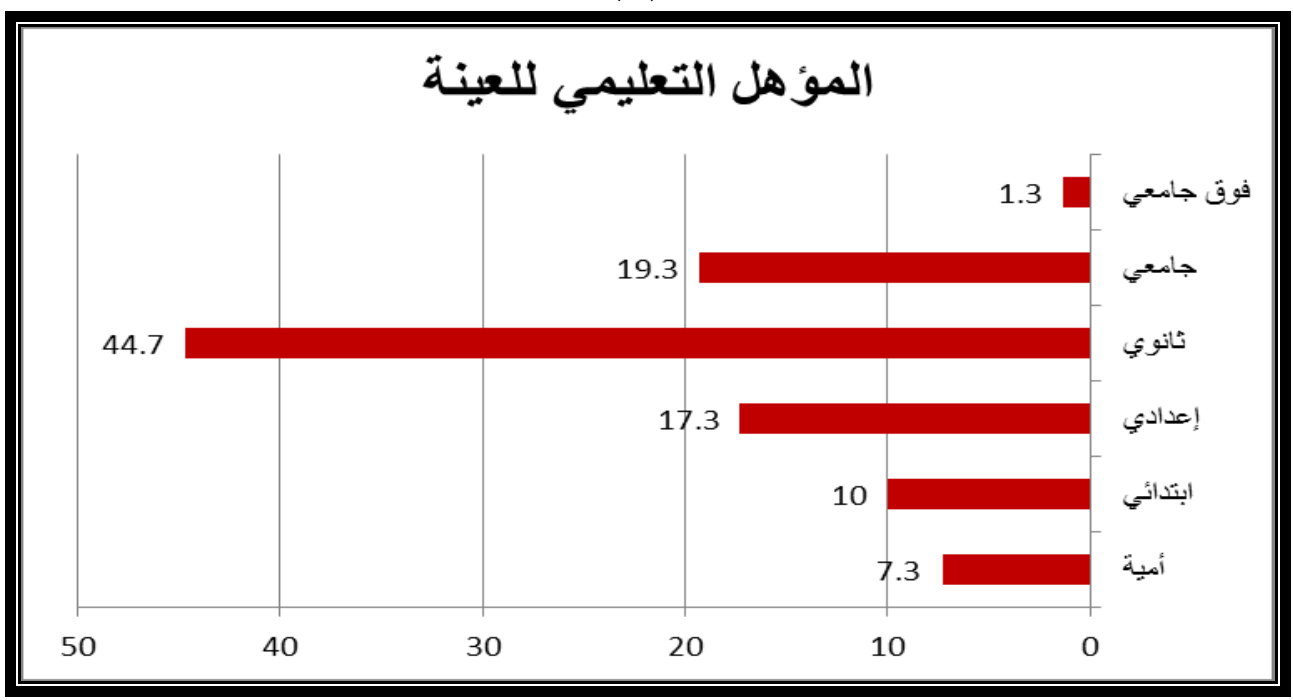

وفيما يتعلق بالمؤهل التعليمي تشير البيانات الميدانية الى ارتفاع نســبة الحاصلين على ثانوى بنسبة V. ؟ ؟\% يليهم الحاصلين على مؤهل جامعى بنسبة

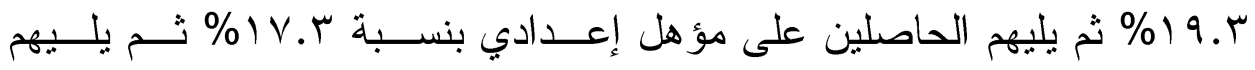

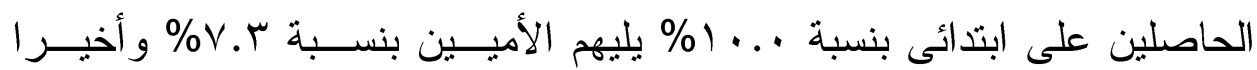
الحاصلين على مؤهل فوق الجامعى بنسبة ب. (\% . وتشير هذه البيانات إلى أن غالبية العينة تقع في فئة التعليم المتوسط فأقل وهو ما يؤكد على انخفاض مستوى التعليم لدى المر أة الفقيرة. ويمثل التعليم أداة تمكينية، ووسيلة حماية من الفقر بمعنــاه الاقتصـــادي و الثقافي والمعرفي فهو حماية لهن من فقر الوعي بحقوقهن. هو الطريق لتحقيق 
مكانة للمر أة في المجتمع فتتولى مثل الرجل أعلى المناصب، وتؤكد على أنهــا قادرة على اتخاذ قر ار اتها داخل و خارج أسرتها. r الأوضاع الاجتماعية والاقتصادية للمر أة الفقيرة:

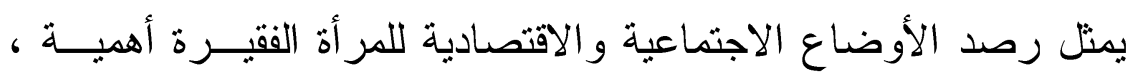
حيث بكثف عن طبيعة الضغوط و المعاناة التي تتعرض لها المر أة، سواء كانت هذه الضغوط من داخل الأسرة، أو من داخل المجتمع، حيث تتعـرض وض المــر أة الفقيرة للعديد من الضغوط، خاصة في ظل تحملها للمسئولية الاقتصادية للأسرة سو اء بمفردها أو مع الرجل، وهو ما يمكن أن يوضح أهمية الحماية الاجتماعية لهذه المر أة ، و أساليب هذه أوديع الحماية.

جدول(r): مدى عمل المرأة

\begin{tabular}{|c|c|c|}
\hline$\%$ & العدد & هل تعملين؟ \\
\hline$\wedge \wedge .$. & ITr & نعم \\
\hline IY.. & 11 & $y$ \\
\hline $1 \ldots$ & 10. & الإجمالي \\
\hline
\end{tabular}

وفيما يتعلق بمدى عمل المرأة تشير البيانات الميدانية الى ارتفاع نسـبة

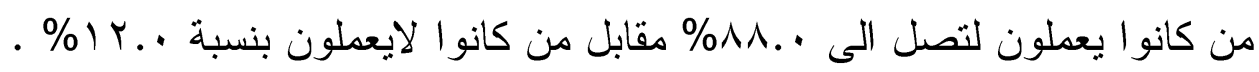

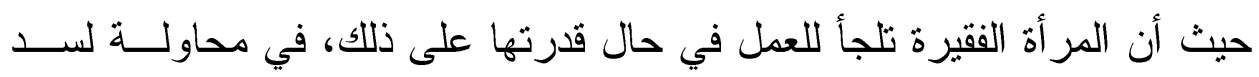
احتياجاتها، ومو اجهة الفقر، وتحقيق الأمان الاجنماعي والاقتصادي.

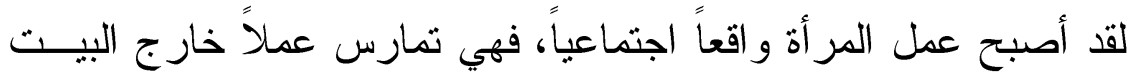
لدى المجتمعات كافة، وان نسبة مشاركتها في العمل في تز ايد مستمر مع ارتفاع

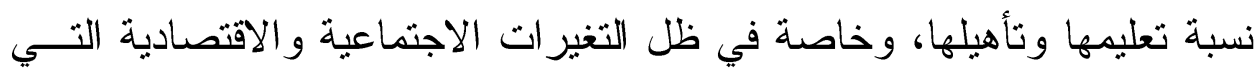

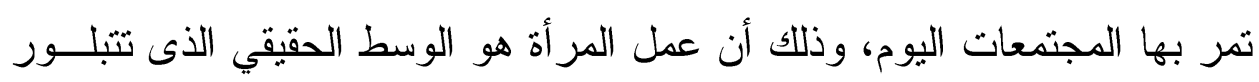

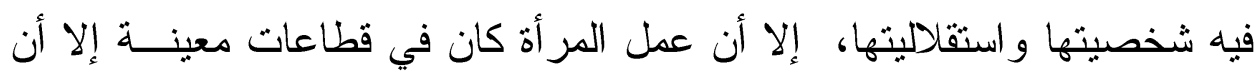

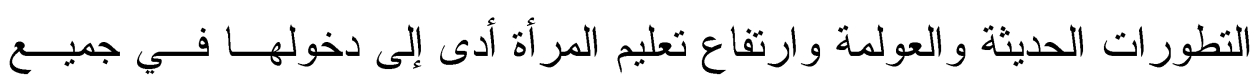

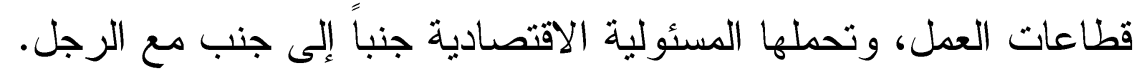




\section{جدول(r): طبيعة عمل المرأة}

\begin{tabular}{|c|c|c|}
\hline$\%$ & العدد & ماطبيعة عملك؟ \\
\hline צ. & س & عاملة في مصنع / شركة \\
\hline$\varepsilon \neg . Y$ & 71 & أخدم في البيوت \\
\hline & $\leq 7$ & أبيع خضـار في الشـارع \\
\hline $1 \ldots$ & ITr & الإجمالي \\
\hline
\end{tabular}

وفيما يتعلق بطبيعة العمل تشير البيانات الميدانية الى ارتفاع نسبة الذين

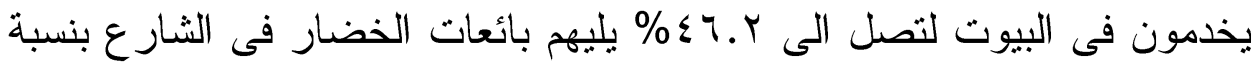

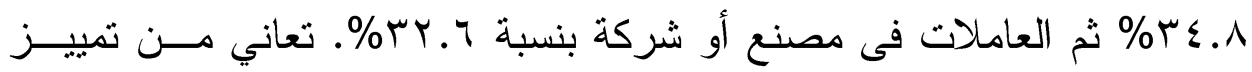
نوعي في العمل، وهو الأمر الذي يدفع بالنساء إلى التركز في الأعمال الهامشية

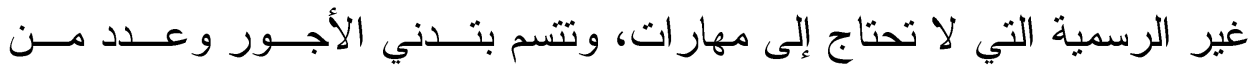

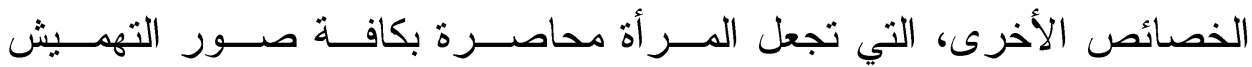
الاقتصـادي.تؤكد هذه البيانات على أن المر أة الفقيرة تعمل في أعمال هامشـية،

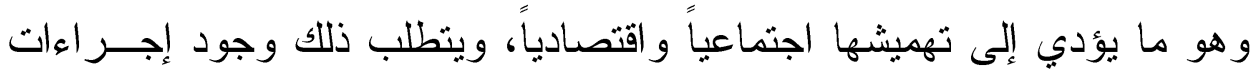

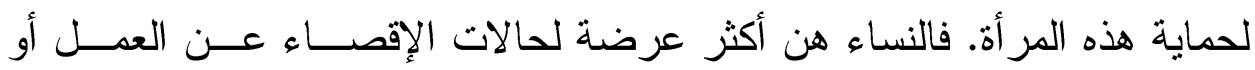
التركيز في قطاعات محددة أو الالتحاق بقائمة العاطلين أو الباحثين عن عمل أو الذين يعانون من فقر مدقع · 


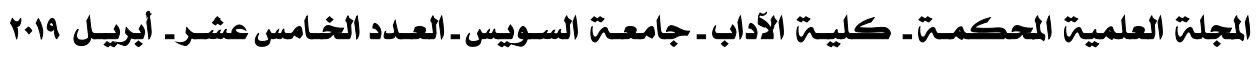

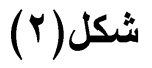

\section{مدى كفاية دخل الأسرة لمتطلباتها}

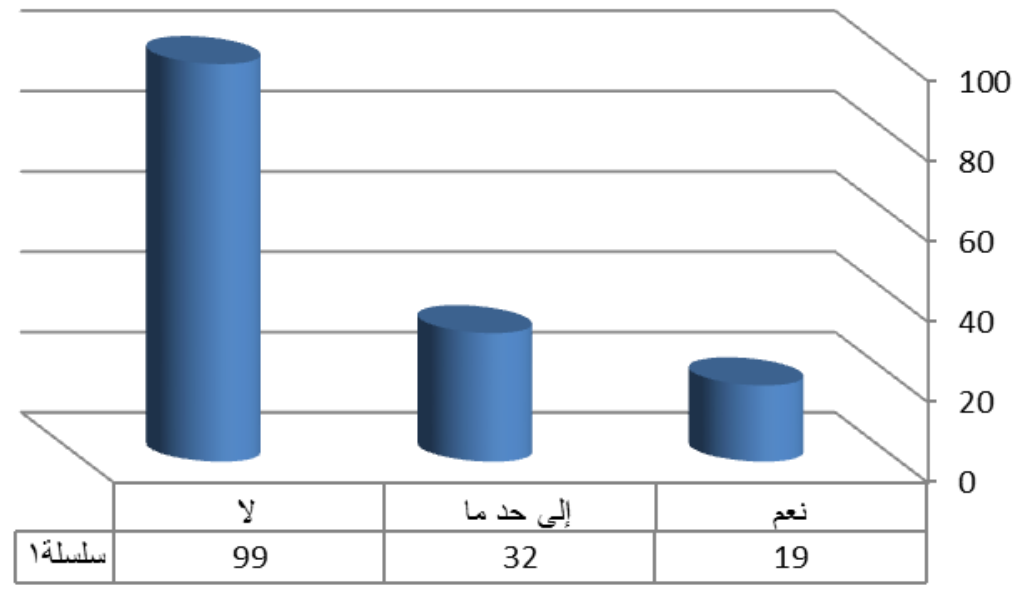

يربط الاقتصاديون بين الفقر ونقص الدخل ولكن الاجتماعيين يــرون أن الفقر لا يعني نقص الدخل فقط ولكنه يرتبط بالحقوق و العلاقات وكيفية تعامـلـل الناس فيما بينهم ونظرتهم إلى أنفهر بالإضافة إلى عدم ملائمة الدخل.

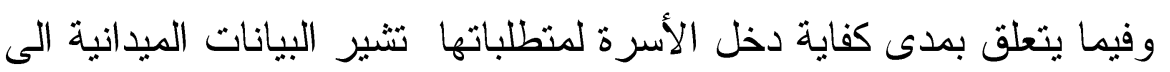
ارتفاع نسبة من كان دخلهم لايكفى بنسبة تصل الى ..47\% فى حين أن نسـبـة

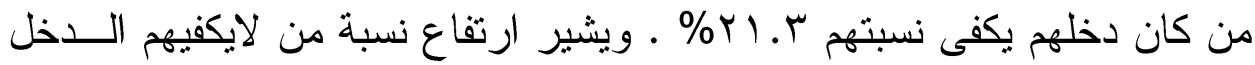

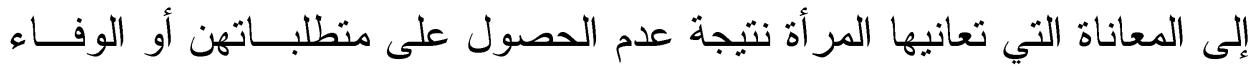
باحتياجاتهن، و هو ما يؤكد على ضعف الحماية الاجتماعية للمر أة الفقيرة . جدول(§) ): مدى تعرض المرأة الفقيرة للعنف

\begin{tabular}{|c|c|c|}
\hline$\%$ & 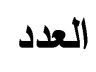 & هل تتعرض المر أة الفقيرة للعنف؟ \\
\hline $01 .$. & NV & نعم \\
\hline$\varepsilon r .$. & זי & إلى حد ما \\
\hline- & - & y \\
\hline $1 \ldots$ & 10. & الإجمالي \\
\hline
\end{tabular}


يعد العُفْ ضدّ المر أة أحد أخطر الظواهر الاجتماعية الثــائعة، وفيمـــا يتعلق بمدى تعرض المر أة الفقيرة للعنف تشير البيانات الميدانية الى ارتفاع نسبة

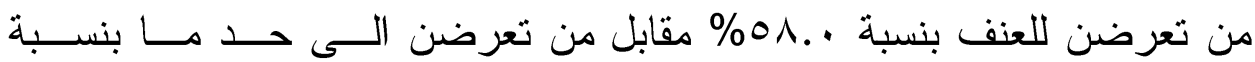

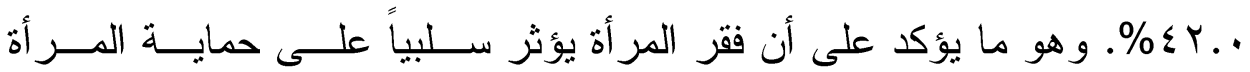
وشعور ها بالأمان الاجتماعي، فمن خلال الملاحظة و الدراسة الميدانية للباحــث

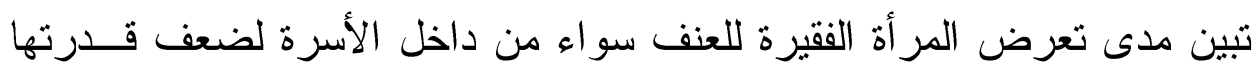

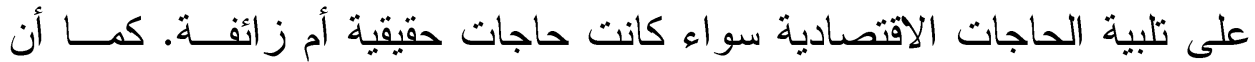
الجيران أو سكان المنطقة لايتعرضون بالعنف اللفظي أو غير اللفظـي للمــر أة

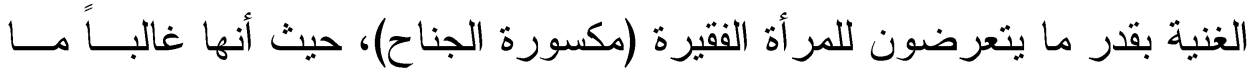
تكون ضعيفة، إضافة إلى العنف الذي تتعرض له المر أة في أماكن العمل ســـو اء في المصانع أو المنازل وغيرها من المجالات الهامشية. رغم أن ظاهرة العنف الممارسة بحق النساء هي ظاهرة عالمية تشمل جميــع المجتمعــات المتقدمــة

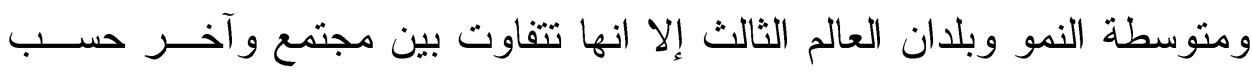
مستوى التقدم الحضاري ، وحسب الوضع الطبقي والاقتصادي في نفس الوقت. ونوصلت دراسة بنيني، أحمد (T ا • ب) أن العنف ضد المر أة الفقيرة لاز ال قائماً. جدول(0): صور العنف الأي تتعرض له المرأة الفقيرة

\begin{tabular}{|c|c|c|}
\hline$\%$ & 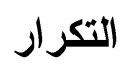 & ماصور العنف الأي تتعرض له المرأة الفقيرة؟ \\
\hline$\Lambda \cdot . \vee$ & $|r|$ & العنف الاقتصادي \\
\hline$\varepsilon 9.1$ & $\vee \leq$ & 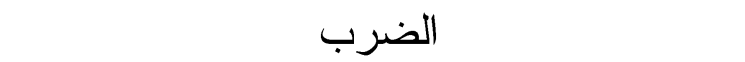 \\
\hline \multirow[t]{2}{*}{$q \cdot . v$} & 1ry & الإهانة اللفظية \\
\hline & 10. & تنسب النتائج الى \\
\hline
\end{tabular}

لا يقتصر العنف على المظاهر المباشرة "الجسدية" ولكنه يتعدى ذلك إلى المظاهر النفسية والمعنوية التي لا تقل خطورة عن العنف الجسدي مــن حبــث ترسيخ دونية المر أة وتهميشها ومحاولة الحط من كر امتها وتحميلها المسؤوليات 
الكاملة عن كافة الأخطاء و السلبيات التي تتم بالأسرة وحرمانها حقها بالتعبير عن نفسها.

وفيما يتعلق بصور العنف الذى تتعرض له المرأة الفقيرة تشير البيانات الميدانية الى ارتفاع نسبة الاهانة اللفظية لتصل الى V. . .9\%، وهى غالباً ماتكون

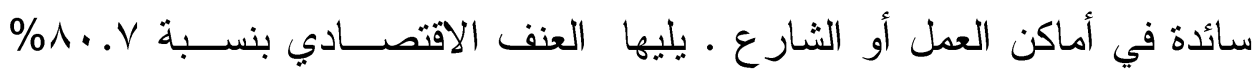
ويكون في الأماكن المختلفة بالحرمان حتى من عائــد عملهــا، او عــدم تلبيـــة

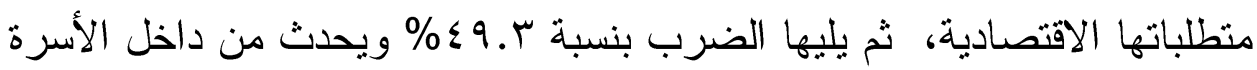
سو اء كان الزوج أو الإبن ، وأحيانا ما بحدث في أماكن أخرى استخلالا لحاجتها الشديدة وصعوبة مقاومتهن نتيجة للفقر وعدم الاستقلال المادي لدى فئة كبيرة من الأن النساء، مما يدفعهن لقبول العنف و السكوت عليه مقابل الاحتياج المادي لصعوبة

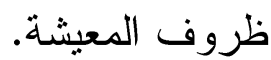

\section{شكل) (r) (r) (1)}

\section{مدى معاناة المرأة الفقيرة من مشكلات صحية}

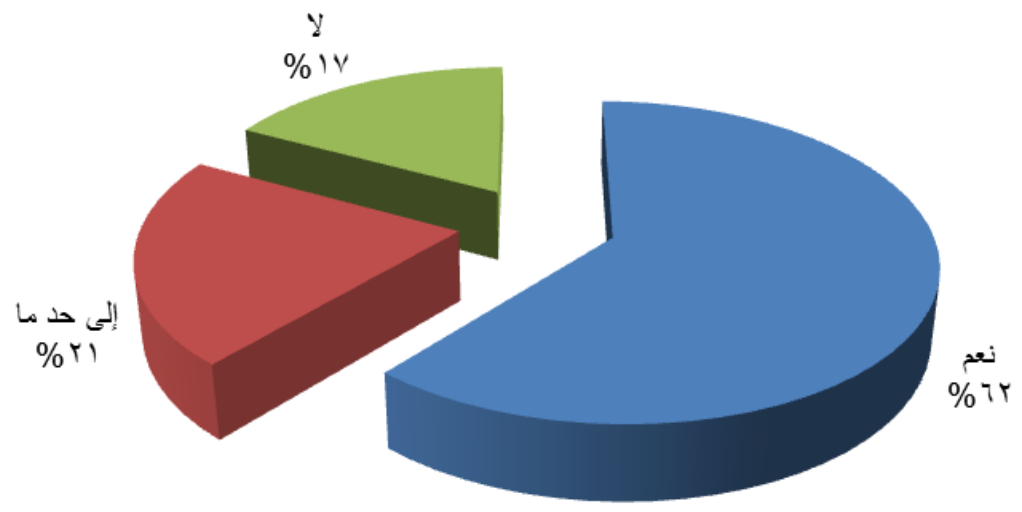

تشير البيانات الواردة بالثكل السابق ارتفاع نسبة النساء اللاتي يعـانين من مشكلات في الحصول على رعاية صحية لتصل إلى با7\% ، وتصل نسـبة من تعانين إلى حد ما لتصل إلى ابץ\%. وهو ما يؤكد على معاناة المرأة الفقيرة 
لمشكلات صحية سواء تعلقت بأوضاعها الصحية الناتجة عــن الفقـر أو فـي الحصول على خدمة صحية مناسبة.

جدول(7): المشكلات الصحية التي تعاني منها المرأة الفقيرة

\begin{tabular}{|c|c|c|}
\hline$\%$ & 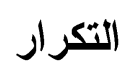 & طبيعة المشكلات الصحية؟ \\
\hline r & £० & مشكلات تتعلق بسوء التغذية \\
\hline 0. & Tr & عدم جودة الخدمات الصحية المجانية \\
\hline 17.9 & r) & طول قائمة الانتظار في بعض المستشفيات \\
\hline \multirow[t]{2}{*}{ vo } & $q \pi$ & ارتفاع تكلفة العلاج \\
\hline & IY & تتسب النتائج الى \\
\hline
\end{tabular}

توضح البيانات الميدانية تعدد المشكلات الصحية التــي تواجــه المـــرأة

الفقيرة وتتمثل في ارتفاع تكلفة العلاج بنسبة \% م حيث ارتفعت بشكل غيــر مسبوق أسعار الكشف والأدوية بثي لم يعد الفقراء قادرين على الحصول على علاج مناسب، وعدم جودة الخدمات الصحية المجانية بنسبة ، \%\% ويتضح ذلك من محاولة الحصول على خدمة صحية من المستشفيات الحكومية حيث يتضح سوء المعاملة، و الإهمال، إضافة إلى الوصفات الجاهزة التي يعطيهــا الأطبــاء للمرضى على اختلاف أمر اضهم، ومشكلات تتعلق بسوء التخذية بنسبة ب.بr\% حيث تعاني الأسر الفقيرة من سوء التخذية نتيجة عدم اهتمامهح بنــوع الأغذيـــة

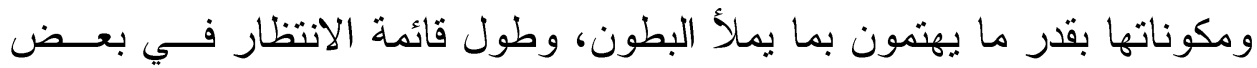

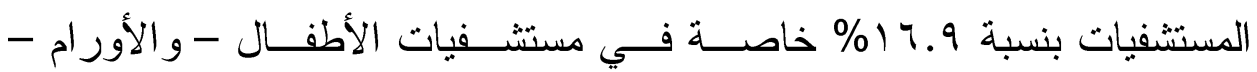
و السرطان و غير ذلك من المستشفيات التي يتعذر على الفقر اء إيجاد بدائل للعلاج

r) أساليب حماية المرأة من الفقر : تعد أساليب حماية المرأة من الفقر آلية من آليات الأمســان الاجتمــاعي المرحلية للتخفيف من البؤس ومكافحة الفقر وتمكين بعض فئات المجتمع خاصة 


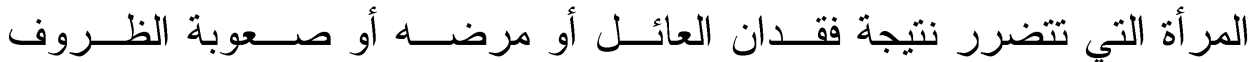

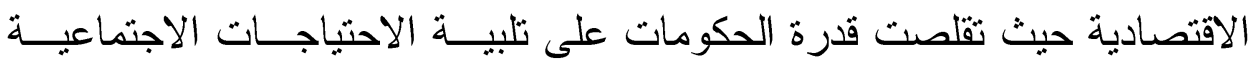
إضـافة إلى ارتفاع الأسعار و انخفاض الدعم نتيجــة تبنـــي الحكومــة بـــر امج الإصلاح الاقتصادي و التكيف الهيكلي. جدول): المؤسسات الحكومية والأهلية ومواجهة الفقر لاى المرأة

\begin{tabular}{|c|c|c|}
\hline$\%$ & العدد & هل تهتم المؤسسات الحكومية والأهلية بمواجهة \\
\hline$\varepsilon \wedge$ & VY & نعم \\
\hline or & $\vee \wedge$ & إلى حد ما \\
\hline- & - & $\gamma$ \\
\hline $1 \ldots$ & 10. & الإجمالي \\
\hline
\end{tabular}

وفيما يتعلق بمدى اهتمام المؤسسات الحكومية و الأهلية بمواجهة الفقــر لاى المر أة تشير البيانات الميدانية الى ارتفاع نسبة من يرى اهتمام المؤسسـات

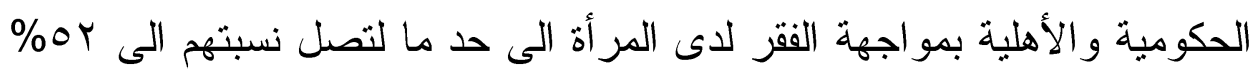
مقابل من اهتموا بنسبة ^^٪\% . ويمكن يرجع ذلك إلى أسلوب اختبار العينة حيث تمت من النساء اللاتي يستفدن من المؤسســات الحكوميــة، ويحصــلن علــى مساعدات أو وسائل رعاية من هذه المؤسسات. كما توصلت دراسة مهى قطاع

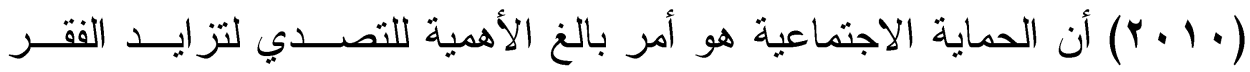

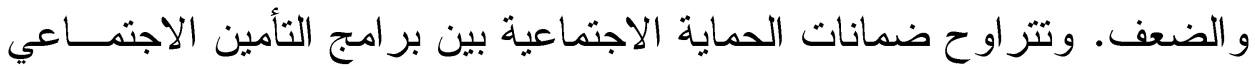
و غير ها من البر امج. 
جدول(^): أساليب المؤسسات الحكومية والأهلية لمواجهة الفقر عند المرأة

\begin{tabular}{|c|c|c|}
\hline$\%$ & 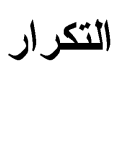 & ما أساليب المؤسسات الحكومية والأهلية لمواجهة الفقر \\
\hline ov.r & $\wedge T$ & صرف مساعدات شهرية (ضمان اجتماعي) \\
\hline rᄉ & $\varepsilon r$ & الدعم النقدى "تكافل وكر امة" \\
\hline $9 . r$ & $1 \varepsilon$ & صرف مساعدات لأبنائهن الطلاب \\
\hline 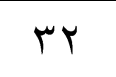 & $\varepsilon \wedge$ & عمل بطاقات صحية للأطفال \\
\hline rq.r & 09 & تقديم قروض لعمل مشرو عات خاصة \\
\hline $1 \cdots$ & 10 & تتسب النتائج الى \\
\hline
\end{tabular}

تتعدد أساليب المؤسسات الحكومية والأهلية لمواجهة الفقر عنــــ المـــرأة وتتمثل في: صرف مساعدات شهرية (الضمان الاجتماعي) بنسبة س. \% \% حيث يقوم الضمان الاجتماعي بصرف مساعدات اجتماعية نقدية للأسر المحتاجة لذلك و التي لا تتو افر لديها شروط الشمول بمعاشات الضمان الاجتماعي، ويتكفل نظام

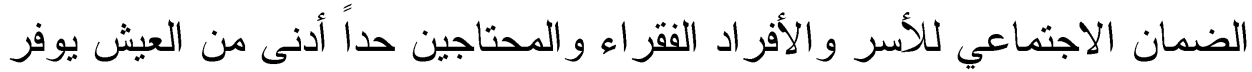
لهم حباة كريمة ويرفع عنهم ذل المسألة ويحفظ كر امتهم. وقد صــفـ الضــمان

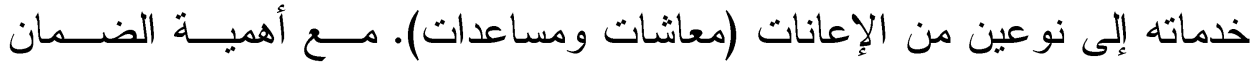
الاجتماعي إلا أن هناك بعض الثروط غير المنطقية في الاستفادة من الضــمان الاجتماعي • حيث تستبعد المر أة العاملة أو تقل مخصصاتها حتـى وإن كانــــ تعمل بأجر زهيد يساهم في تأمين أوجه الإنفاق الضرورية و المتعددة في العصر الحاضر من غذاء وسكن وكهرباء وماء وهاتف وملبس وتعليم وعلاج وما إلـى ذلك. وتؤكد دراسة الضــبع (ب ا ـ r) أن بر امج المأسسة التي تحصــل مــن خلالها النساء على إعانات مالية من الدولة لا تحقق لهن أي نـــوع مــن الأمــن

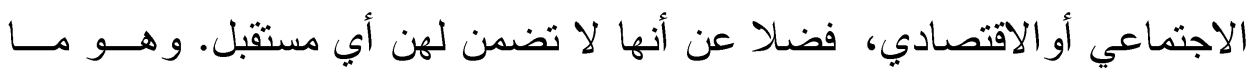


يتطلب إقامة مشروعات انتاجية وتتمية مهار ات المر أة كأحسـد أســاليب التتميــة المستدامة.

تقديم قروض لعمل مشرو عات خاصة بنسبة س.9 \% وقد ظهرت آليــة القروض الصغيرة كو احدة من الآليات التي تبنتها الدولة وكذلك المنظمات غيــر

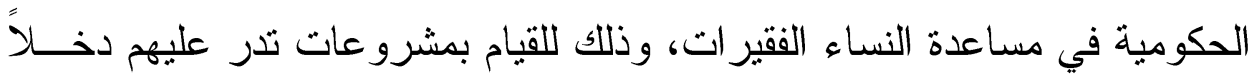

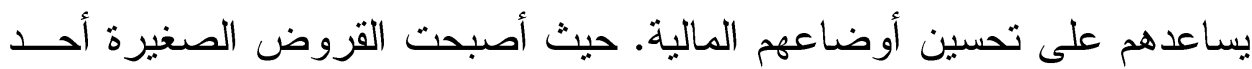

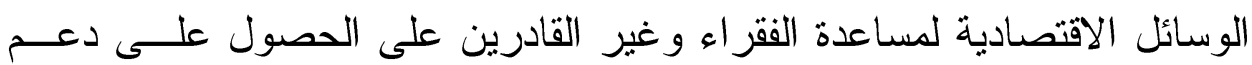
مالي من الجهات المتخصصة كالبنوك. وقد بدأت آلية القروض الصغيرة منذ عام I 9VA عن طريق الاقتصادي البنغالي محمد يونس الحاصل على جائزة نوبــلـ للسلام عام Y . . T، وكانت الفكرة هى إقر اض نساء معوز ات دون فائدة، حبــث أسس بنك "جر امين" للقضاء على الفقر في بنجلاديش ويقدم القــروض الماليــة

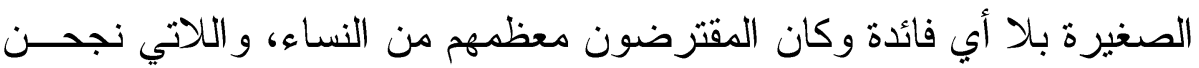

$$
\text { وارتفع مستوى معيشتهن( (1). }
$$

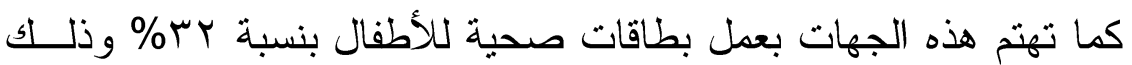
أن هذه البطاقات ترفع العبء عن كاهل الأسرة فيما يتعلق بالرعايــة الصـــية للأبناء. حيث تستقطع الرعاية الصحية جزء من الدخل لايمكن للأسرة الفقيرة أن

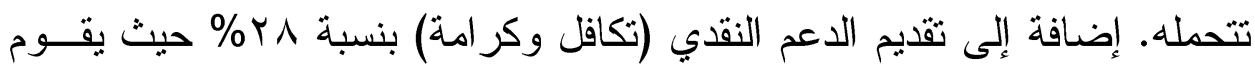
نظام الضمان الاجتماعي و الدعم النقدى "تكافل وكر امة" بمساعدة بعض الأســر

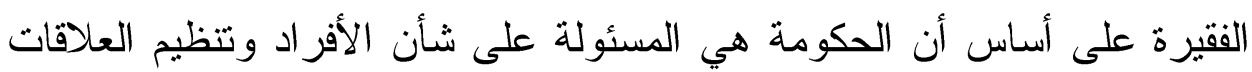

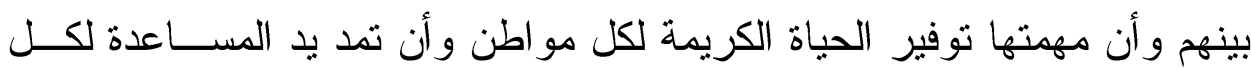

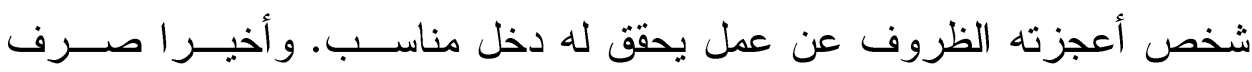

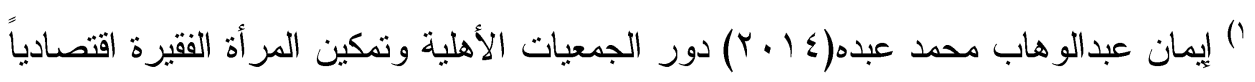

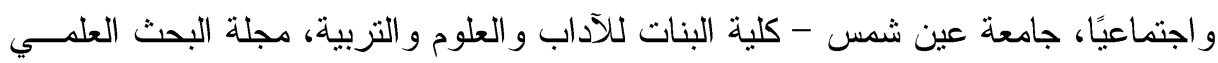

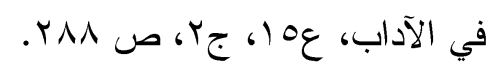


مساعدات للطلاب بنسبة ؟.9\% : وذلك لمواجهة أعباء التعليم و المو اصلات من

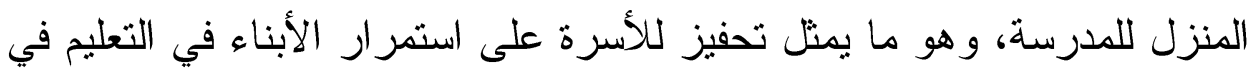
ظل عدم القدرة على تلبية احتباجات الأبناء الطلاب، و لاشك أن هذه المساعدات

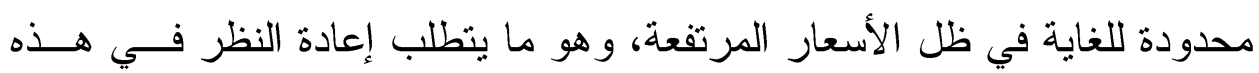

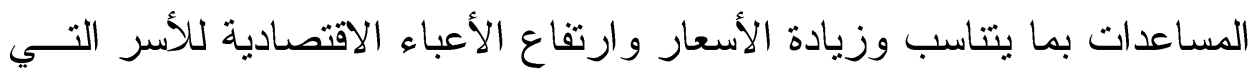

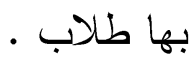

ع - أساليب توعية وتأهيل المرأة: جدول رقم (9): مدى الحصول على استثارات اجتماعية من الجهات المختلفة

\begin{tabular}{|c|c|c|}
\hline$\%$ & ك & هل تحصلين على استشارات اجتماعية من الجهات التالية: \\
\hline ro.r & or & وزارة التضامن الاجتماعي \\
\hline Tร.V & $9 V$ & المجلس القومي للمر أة \\
\hline rV & 07 & الجمعيات الأهلية \\
\hline $1 \cdots$ & 10. & المجموع \\
\hline
\end{tabular}

تشير التحليلات الإحصائية فيما يتعلق بمدى الحصول على استشـــار ات اجتماعية من الجهات المختلفة الى ارتفاع نسبة الاستشار ات من خلال المجلـس

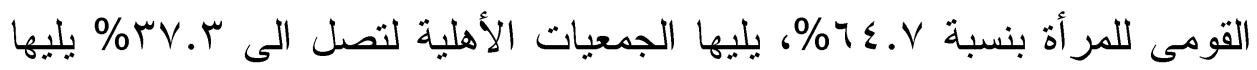
ثم يليها وزارة التضامن الاجتماعى بنسبة س.0\%\%. و لاشك أن المجلس القومي للمر أة يهتم بصورة أساسية بعقد الندوات وورش العمل لتوعية وتثقيــف المــر أة بحقوقها، و أساليب الحصول على هذه الحقوق، كما تهتم الجمعيات الأهلية أيضـــاً إلى جانب تقديم الخدمات و المساعدات بتوعية وتثقيف المر أة. في الوقت الــذي

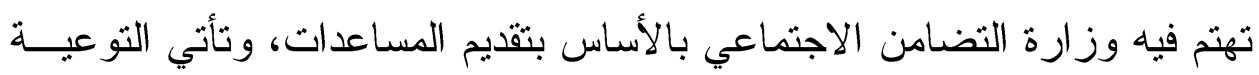
و تقديم الاستشار ات في مرتبة منخفضة. 
جدول( • 1): المؤسسات الحكومية والأهلية وتدريب وتأهيل المرأة الفقيرة

\begin{tabular}{|c|c|c|}
\hline$\%$ & ك5 & هل تحصلين على دورات تدريبية وتأهيلية من الجهات التالية: \\
\hline$\varepsilon 1.1$ & Tr & وزارة التضامن الاجتماعي \\
\hline rᄉ & $\varepsilon r$ & المجلس القومي للمر أة \\
\hline$r \cdot v$ & $\sum \uparrow$ & الجمعيات الأهلية \\
\hline $1 \ldots$ & 10. & المجموع \\
\hline
\end{tabular}

تشير التحليلات الإحصائبة فيما يتعلق بتدريب وتأهيل المرأة الفقيرة من

خلال الدورات التذريبية الى ارتفاع نسبة من حصلوا على الدورات من خــلال

وزارة التضامن الاجتماعي بنسبة س. ؛ ٪.

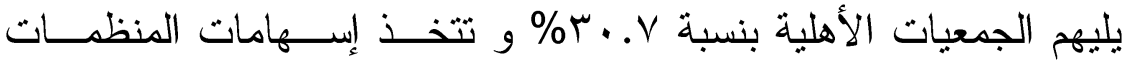

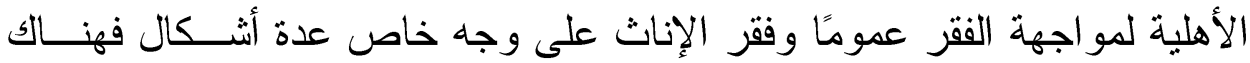

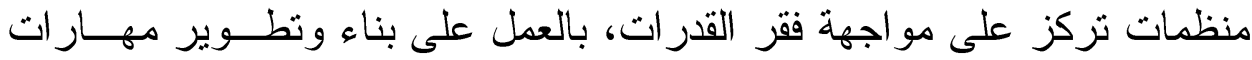
النساء كبر امج محو أمبة النساء و التوعية الصحية وتعليم الفتيات المتسربات من التعليم، وهناك منظمات أخرى نركز على مساعدة النساء في إقامة المشروعات الصغيرة المدرة للاخل سواء من خلال دورها كوسيط بين الصندوق الاجتماعي وبين النساء، أو من خلال ثقديم القروض عن طريق تدبير موارد مــن جهـات مانحة أجنبية.

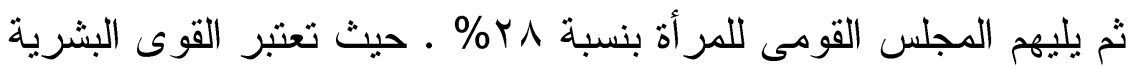

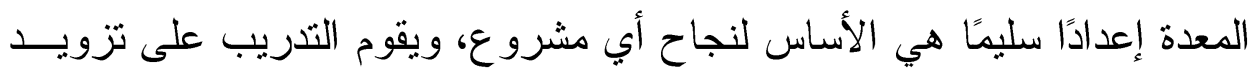
المتدربين بالأساليب و الخبرات اللازمة لتعديل اتجاهاتهم وتتمية مهار اتهم وزيادة التهات معارفهم من خلال مجموعة الأدوار التي يؤديها القائمون بالعملية التدريبية بكفاءة و اقتدار، مستهدفين بذلك تحقيق مخرجات التــدريب و التتميــة المحــددة ســلفا.

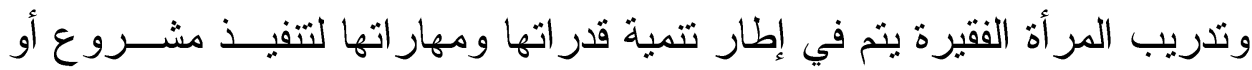
القيام بعمل يحقق لها دخل يساعدها على مواجهة أعباء المعيشة، ويمكن أن يــتم تدريبها على حرفة تساعدها على الحصول على عمل لتحقيق دخل يكفي الأسرة. 
جدول(1 1 ): أساليب المؤسسات الحكومية والأهلية في حماية المرأة من العنف

\begin{tabular}{|c|c|c|}
\hline$\%$ & 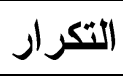 & أساليب المؤسسات في حماية المرأة من العنف: \\
\hline $0 \xi . V$ & Ar & عن طريق وجود خط ساخن لاستقبال شكاوى المعنفات \\
\hline 01.1 & $V V$ & تو عية المر أة بحقوقها \\
\hline 10.1 & ru & توفير محامين للدفاع عن حقوق المر أة مجاناً \\
\hline \multirow[t]{2}{*}{$\leqslant 7$} & 79 & التوعية بالأثار السلبية لممارسة العنف ضد المراة \\
\hline & 10. & تتسب النتائج الى \\
\hline
\end{tabular}

لاشك أن حماية المرأة من العنف يمثل أحد أولويات المؤسسات الحكومية

وتتظيمات المجتمع المدني، خاصة المر أة الفقيرة التي لاتســنطيع الــدفاع عــن نفسها. وتشير البيانات الميدانية فيما يتعلق بأساليب المؤسسات الحكومية و الأهلية

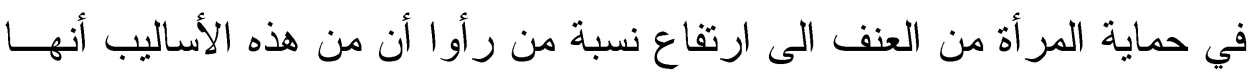
تتم عن طريق وجود خط ساخن لاستقبال شكاوى المعنفات لتصل الى V. ؟0\%؛ و لاشك أن الخط الساخن يساعد على تلقي الشكاوى دون الإفصاح عن الهوية إلا لادى المتعاملين مع الحالة، وعدم إذاعة أسرارها حتى لاتتعرض لحرج اجتماعي

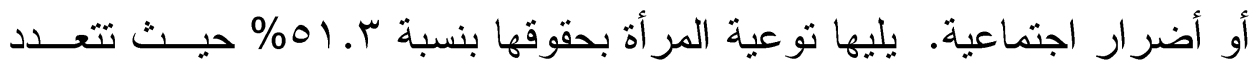

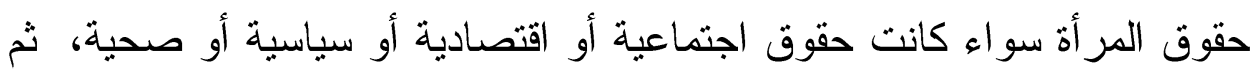
يليها التوعية بالآثار السلبية لممارسة العنف ضد المرأة بنسبة بـ؛ حيث يؤثر العنف على المر أة نفسيا واجتماعيا كما يؤثز على الأطفال وأخير ا توفير محامين

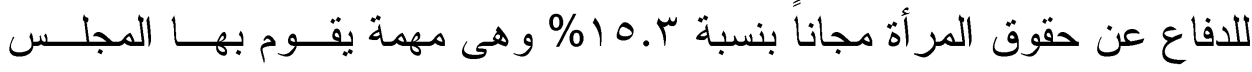
القومي للمر أة ، وذلك لمساعدة المر أة الضعيفة التي لاتعرف حقوقها أو مساعدتها على الوقوف في وجه المعنفين. يرتبط المرض وبصفة خاصة أنواع منه بحالة الفقر التي تكون عليهــا الأسرة والمجتمع وذلك لقلة الموارد من جهة ولضعف الوعي من جهة أخــرى ولقصور التغذية من جهة ثالثة ، أو لما ينشأ عنها من ظروف ويتصل بها مــن ملابسات نؤدي كلها إلى انعدام الصحة وقائياً و علاجياً. 
جدول(Y I): الرعاية الصحية للمر أة الفقيرة

\begin{tabular}{|c|c|c|}
\hline$\%$ & التكر ار & ما الرعاية الصحية التي تحصلين عليها؟ \\
\hline r) & rr & عن طريق الوحدات و المر اكز الصحية \\
\hline $19 . r$ & rq & مر اكز الأمومة و الطفولة \\
\hline$\vee \varepsilon . V$ & $11 \mathrm{r}$ & عن طريق المسنشفيات \\
\hline rt & $\varepsilon \wedge$ & عن طريق المستوصفات \\
\hline $1 \cdot . v$ & 17 & بتقديم العلاج المجاني \\
\hline $1 \varepsilon$ & Y) & بعمل الفحوصات و الأشعة مجاناً \\
\hline $1 \ldots$ & 10. & تتسب النتائج الى \\
\hline
\end{tabular}

تشير البيانات الميدانية إلى أهمية الرعاية الصحية للهـر أة وذلـــــــــــا تحتاج إلى متابعة وتلقي الخدمة دون نفقات، إضافة إلى أنها لاتجد وقت للكشف و المتابعة، حيث تعد الرعاية الصحية الثاملة بكل جو انبها الوقائية و العلاجية أول

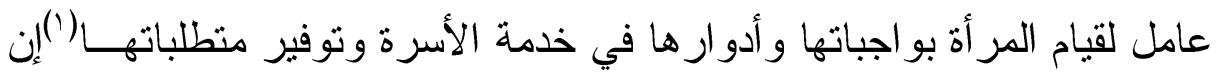
صحة الفرد في المجتمع هي الغاية التي يسعى لتحقيقها المخططون لان التنميــة الصحية أساسية للتتمية الاجتماعية و الاقتصادية فهي القوة الدافعة الحقيقية للتنمية . فالأصحاء من الناس هم أكثر قدرة علــى الإســـهام فــي التنميـــة الاجتماعيــة و الاقتصادية .و هذه التتمية بدور ها تقدم الموارد الإضافية و الطاقة الاجتماعية التي تيسر التتمية الصحية .ولذا فان الفرد في المجتمع بحاجة ماســة إلــى الرعايــة

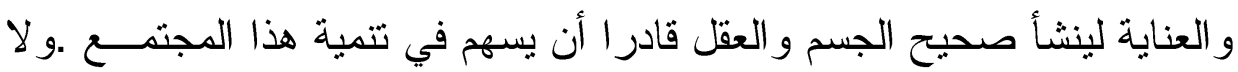
يمكن أن تتوفر هذه الرعاية و العناية إلا في مجتمع منظم وفي وسط عائلي قادر

(') أبو الحمائل و آخرون، (• ( ب). فعالية برنامج مقترح لتتمية الوعي بالصحة الإنجابية لدى

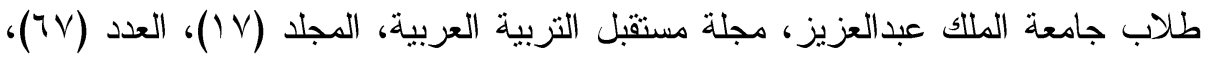

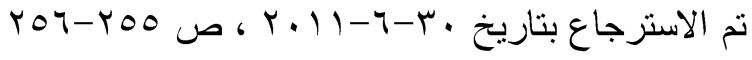


على تأمين حاجة أفر اده منذ و لادتهم حتى يصبحو أقوياء قادرين علــى تحمـلـل مسؤولية أنفسهم في خضم الحياة.

وتوضح البيانات الميدانية تعدد الجهات التي تقدم الرعاية الصحية للمر أة

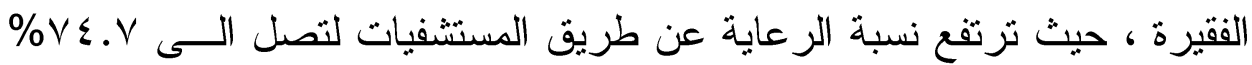
وذلك أن المستشفيات تقدم الخدمات الصحية بمقابل بسيط يمكن أن تتحمله الأسرة الفقيرة، وهى تمثل الملجأ الأول للفقر اء الذين لايستطيعون تحمل نفقات العـلاج الخاص، يليها عن طريق المستوصفات بنسبة rr\% و هذه المستوصفات ثتبـع

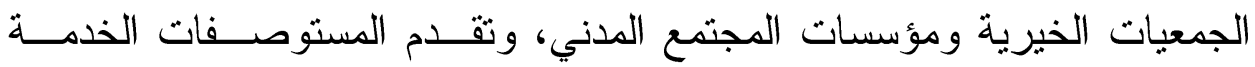
الصحية بمقابل رمزي بالمقارنة بالعيادات و المستشفيات الخاصة، ثم يليها عــن

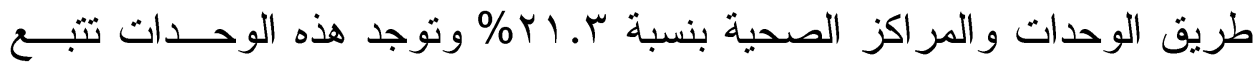
وزارة الصحة وتقدم خدماتها بصورة شبه مجانية، ثم يليها عن طريــق مر اكــز

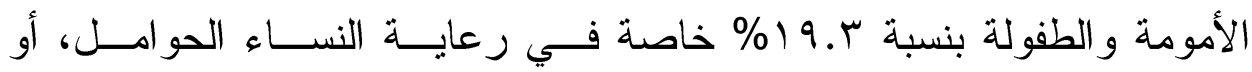
المرضعات يليها عن طريق عمل الفحوصات و الأشعة مجانا بنسبة ع ( \% و أخير ا عن طريق تقديم العلاج مجانى بنسبة V. . (1\%. وتتخفض نسبة من برى عمـلـ

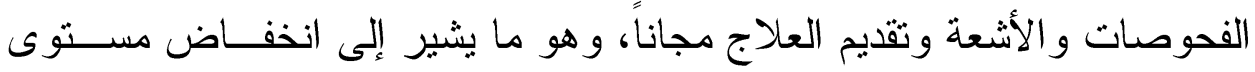
الرعاية الصحية للمر أة الفقيرة، ويتطلب ذلك الاهتمام بالحماية الاجتماعية للمر أة.

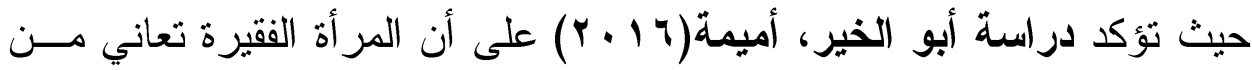

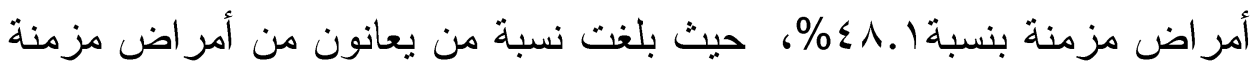

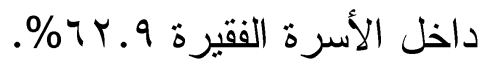

\section{عاشراً: الفتائج العامة للدراسة:}

( ) فيما يتعلق بالأوضاع الاجتماعية والاقتصادية للمر أة الفقيرة: فقد أكدت نتائج الدراسة على:

- ارتفاع نسبة المر أة العاملة ، كما أكدت البيانات على أن هذه المر أة تعهـلـل في أعمال هامشية مثل الخدمة في المنازل، وبائعات، و عاملات في مصانع 
وشركات، وهو ما يؤكد على هشاشة وضع المرأة فــي مجـــال العهـلـل، ويعكس طبيعة معاناتها الاقتصادية، وهو ما يتطلب حماية الاقتصادية. - ارتفاع نسبة من كان دخلهم لايكفى بنسبة تصل الى . . 7\%\%، و لاشك أن عدم كفاية الدخل بيرز الوضع الاقتصادي المأزوم للمر أة الفقيرة، ويوضح

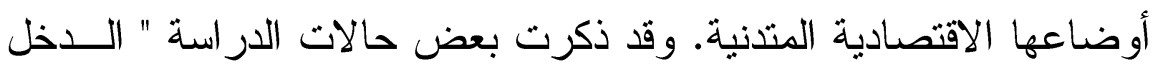
لايكفي على الرغم من أننا نقتصر على الضروريات، ولانشــتري ســلع ترفيهية إلا في أضيق أضيق الحدود، لدرجة أننا نكاد نعاني من الحرمــان

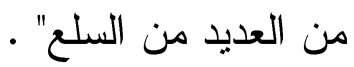
- أن نسبة المر أة الفقيرة التي تعرضت للعنف تصل من . . 1\% وتعددت صور العنف مابين الاهانة اللفظية، العنف الاقتصادي، والضرب، وهو ما يؤكد

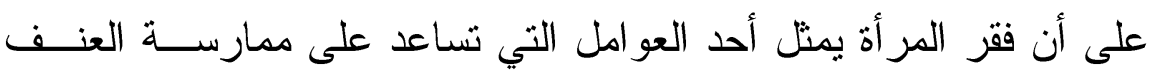
ضدها.

\section{r) وفيما يتعلق بأساليب حماية المرأة من الفقر :} فقد توصلت نتائج الدراسة إلى : - ارتفاع نسبة من يرى اهتمام المؤسسات الحكومية والأهلية بمو اجهة الفقر لدى المر أة، وذللك حيث تحصل النساء الفقير ات على المساعدات الماديــة و غير المادية من هذه المؤسسات، و لاينفي ذلك حصولهن على مســاعدات من الأقارب أو أهل الخير، غير أن المساعدات المؤسسية مستمرة. وتذكر

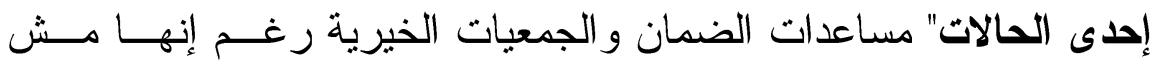
بتكفي بس مضمونة ، أما مساعدات أهل الخير كويسة بتساعد بس ممكـنـ

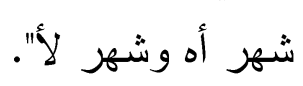

- تتعدد أساليب المؤسسات الحكومية والأهلية لمواجهة الفقر عنــد المــر أة أه وتتمثل في: مساعدات مادية تمثلت في صرف مساعدات شهرية (الضمان الاجتماعي)، عمل بطاقات صحية للأطفال، الدعم النقدي (تكافل وكر امة)

$$
\text { و أخير ا صرف مساعدات للطلاب. }
$$


- ارتفاع نسبة الاستشار ات من خلال المجلـس القــومى للمــر أة ، يليهـــا الجمعيات الأهلية ثم يليها وزارة التضامن الاجتماعي، غيـر أن بعـض النه حالات الدراسة أكدن على رغبتهن في المساعدة الفعلية بتقديم دعم مـادي وليس تقديم الاستشار ات فقط. - ارتفاع نسبة من حصلو ا على الــدورات مــن خــلال وزارة التضــــامن الاجتماعي ثم الجمعيات الأهلية يليهر المجلس القومى للمر أة ـ غير أن هذه الدورات على حد ذكر بعض الحالات لاتساعد بشكل عملي فـي تطــــير أعمال أو إقامة مشرو عات خاصة ناجحة. - تعدد أساليب المؤسسات الحكومية و الأهلية في حماية المر أة من العنف عن طريق وجود خط ساخن لاستقبال شكاوى المعنفات. يليها توعية المــرأة

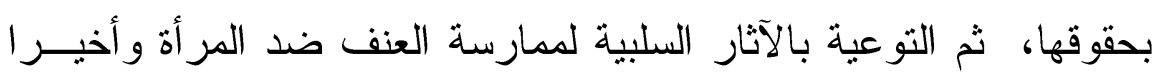

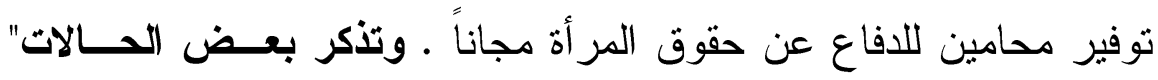

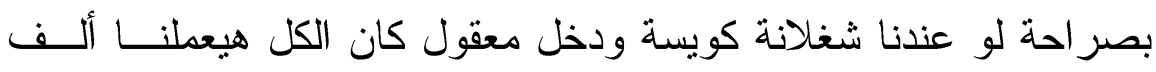

حساب ومفيش حد بدوس على طرفنا".

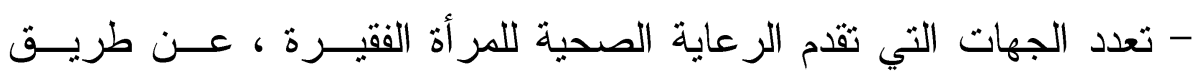

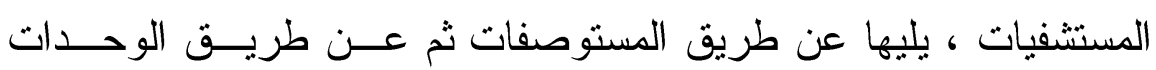

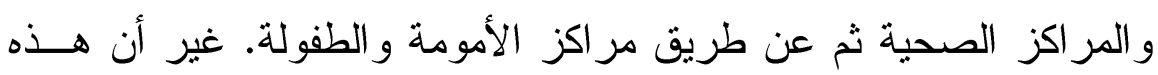
الخدمات ليست على درجة عالية أو منوسطة من الكفاءة ، وهو ما بتطلب مزيد من الاهتمام بتجويد الخدمات الصحية للمر أة الفقيرة.

\section{حادي عشر: تصور مقتزح لتفميل الحماية الاجتماعية للمرأة :}

من خلال عرض نتائج الار اسة يحاول الباحث وضع تصــور مقتـرح

لتفعيل الحماية الاجتماعية للمر أة الفقيرة: عناصر التصور المقترح: 1- أهداف التصور المقترح. 
r-مكونات التصور المقترح.

س- أدوات تطبيق التصور .

ع- آليات تحقيق التصور المقترح.

0- عو امل نجاح التصور • المداف

1 - أهداف التصور المقترح:

- تفعيل وتطوير شبكات الأمان الاجتماعي لمواجهة الفقر لدى المرأة . - زيادة الاهتمام بتقديم الخدمات الصحية المجانية ، وتقديم العلاج و إتاحسـة الفرصة لعمل الفحوصات للمر أة الفقيرة دون تكلفة.

- الاهتمام بعمل ثشريعات تساعد على مواجهة العنف ضد المر أة الفقيـرة سو اء داخل المنزل أو الثار ع أو مكان العمل.

ץ - مكونات التصور المقترح: - مواجهة الفقز لدى المرأة. - الرعاية الصحية للمر أة الفقيرة. - مو اجهة العنف تجاه المرأة. r- أدوات تطبيق التصور :

- الأداة رقم (1): در اسة و اقع الحماية الاجتماعية للمر أة الفقيرة. - الأداة رقم (Y): وضع رؤى وبر امج لمو اجهة فقر المر أة. - الأداة رقم (r): صياغة وتطوير بر امج للرعاية الصحية للمر أة الفقيرة. - الأداة رقم (ع): وضع تشريعات وأساليب لمو اجهة العنف ضد المر أة. 
ع - آليات تحقيق التصور المقترح تتمثل آليات تحقيق التصور المقترح في:

\begin{tabular}{|c|c|}
\hline آليات تحقيق التصور & التصور المقترح \\
\hline & 1- مواجهة الفقر \\
\hline وزارة التضامن الاجتماعي & - تقديم المعاش و الضمان الاجتماعي \\
\hline 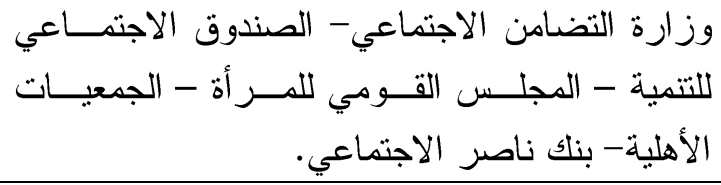 & - تقديم قروض ميسرة للمر أة \\
\hline الجمعيات الأهلية الصنداعي للتنميــة- القــوى العاملــــــ & - التدريب المهني للمر أة الفقيرة \\
\hline القوى العاملة. & - إقامة مشرو ع صغير \\
\hline & r - الرعاية الصحية للفقر اء: \\
\hline التضامن الاجتماعي القومي للمـر أة-وزارة الصــــة - وزارة & - تقديم بطاقات علاجية للفقز اء \\
\hline الهيئة العامة للتأمين الصحي & - إثر الك الفقر اء في التأمين الصحي \\
\hline & r- مواجهة العنف ضد المرأة: \\
\hline 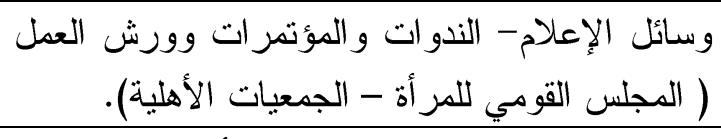 & - تتمية الوعي لدى المر أة بحقوقها. \\
\hline مجلس النواب- المجلس القومي للمرأة) & - وجود تشريعات نو اجه العنف ضد \\
\hline 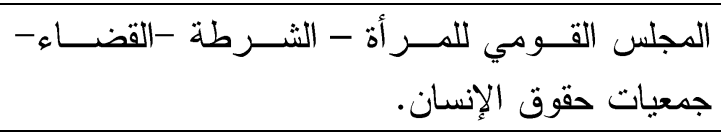 & - الدفاع عن النساء المعنفات \\
\hline 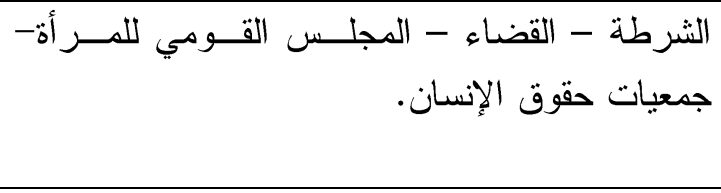 & 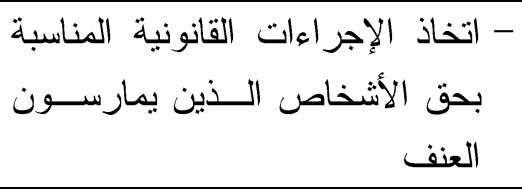 \\
\hline الإنسان. & - وجود خط ساخن لاستقبال شكاوى \\
\hline المجلس القومي للمر أة- جمعيات حقوق الإنسان. & - توفير محامين للدفاع عـنـ حقــوق \\
\hline
\end{tabular}


•- عو امل نجاح التصور :

توجد مجموعة من العوامل التي تساعد على نجاح التصور، تزيد مــن فعالية آليات الحماية الاجتماعية هى : 1- التزام الجهات الحكومية والأهلية بتقديم الحماية الاجتماعية للمرأة الفقيرة.

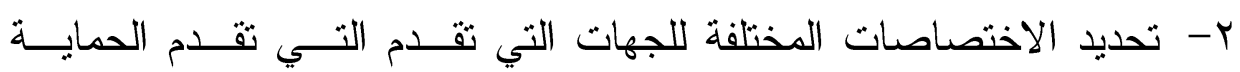
الاجتماعبة للمر أة.

ب- تحديد الأدوات و البرامج المناسبة لقياس الوضع الحالي للحماية الاجتماعية للمر أة وتقويمه. ع - زيادة التعاون بين الجهات المختلفة لتقديم وتحسين بــر امج ومشــروعات الحماية الاجتماعية للمر أة الفقيرة . 0- توفير النشرات، والكتيبات، و البرامج التي تساعد على التوعيــة بحقـوق

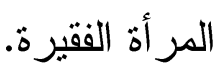




\section{المراجـيح}

أبو الحمائل وآخرون، (· ( • (Y). فعالية برنامج مقترح لتنميــة الــوعي بالصحة الإنجابية لدى طلاب جامعة الملك عبدالعزيز، مجلــة مســقتبل

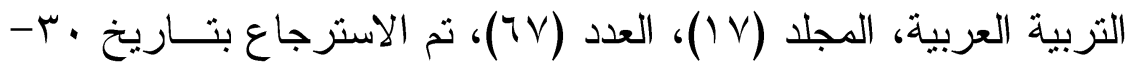
$. r \cdot 11-r$

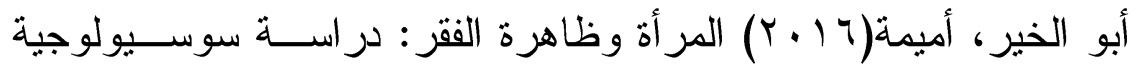
لمعاناة المر أة فى الأسر الفقيرة، الإمار ات ،جمعية الاجنماعيين، شـؤون

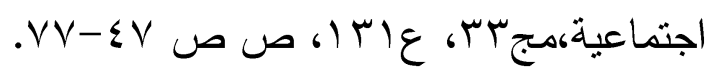
الجهاز المركزي للتعبئة العامة و الإحصـاء، نتـــــــائج بحــث القـوى

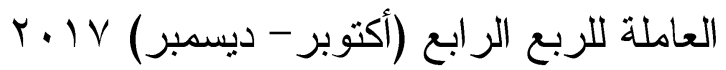
الخمشي، ساره صالح عياده (ع ( + r) دور شبكات الأمان فـي تمكـين المر أة السعودية الفقيرة : الأسر المنتجة أنموذجا، جامعة حلوان - كليــة الخدمة الاجتماعية، مجلة در اسـات فــي الخدمـــة الاجتماعبــة و العلــوم

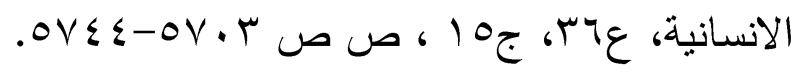

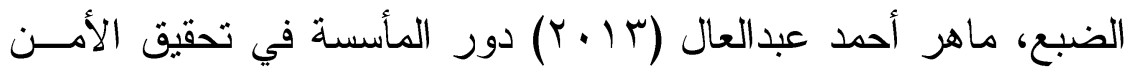
الاجتماعي و الاقتصادي للمر أة الفقيــرة المعيلـــة : در اســـة مســحية ،

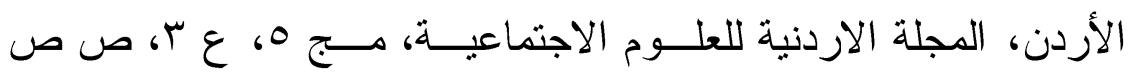
\&). - NO

الفارس ،الرزاق( ( . ب) الفقر وتوزيع الدخل في الوطن العربي، مركز در اسات الوحدة العربية ، بيروت،ط ا. 


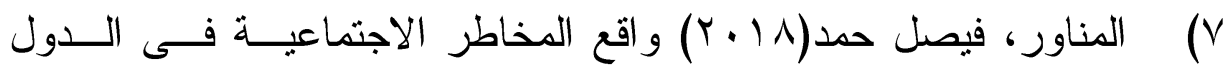

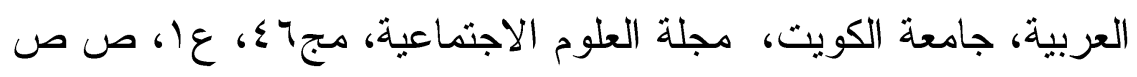
$.07-11$

إيمان عبدالو هاب محمد عبده(؟ ( ب)دور الجمعيات الأهليــة و تمكـين المر أة الفقيرة اقتصادياً واجتماعيًا، جامعة عين شمس - كليــة البنــات للآداب و العلوم و التربية، مجلة البحث العلمي في الآداب، عه ا، جr.

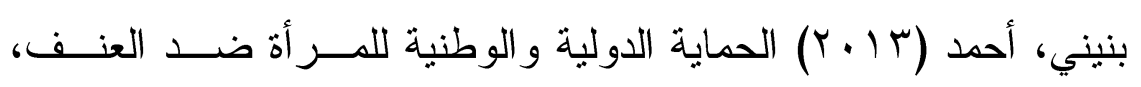
الجزائر، جامعة محمد خيضر بسكرة، مجلة العلوم الانسانية، عYr"، ص

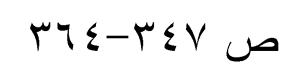

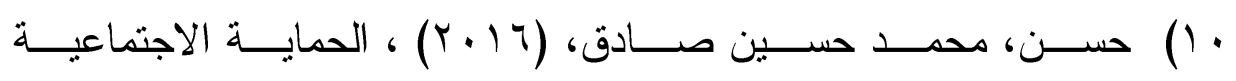
كمؤشر لإشباع الحاجات الصحية للفقر اء، مجلة بحوث الشرق الأوسط ،

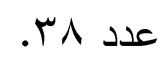

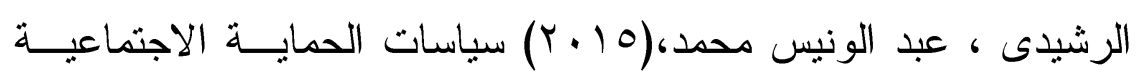
و الحد من مشكلة الهجرة غير الشرعية للشباب،مجلة الخدمة الاجتماعية (

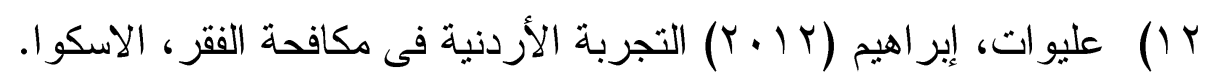

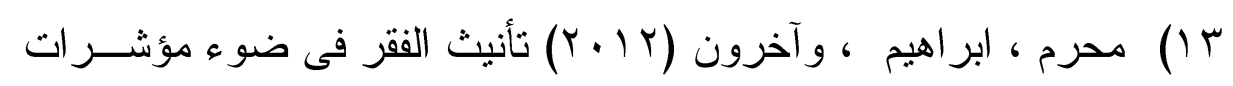
التتمية البشرية و الو اقع الاجتماعي الريفي، مجلة العلــوم الاقتصــادية و الاجتماعية ، جامعة المنصورة، عَ، مجلدم 


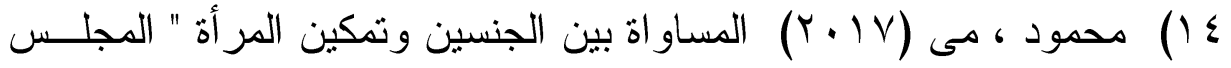

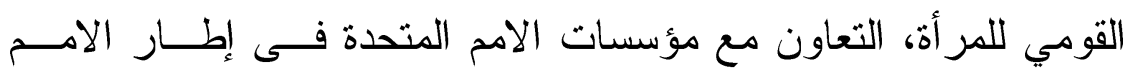

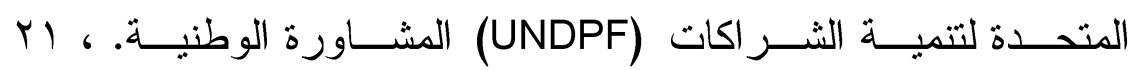

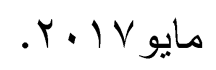

1) مهى قطاع (· ( · ( ) الحماية الاجتماعية للمر أة العاملة في الاقتصاد غير المنظم في سورية بين القانون و الو اقع، جامعة تشرين ، مجلـــة جامعـــة تشرين للبحوث و الدر اسات العلمية - سلسلة العلوم الاقتصادية و القانونية

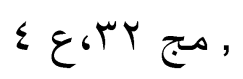

16) Blattman, Christopher, Green, Eric, Annan, Jeannie and Jamison, Julian (2013): Building Women's Economic and Social Empowerment Thruogh Enterprise "Uganda, https://www.poverty-action.org/.../wings

17) Coward, B. E.; Feagin, J. R. and Williams, Jr. J. A. (1973). The Culture of Poverty Debate: Some Additional Data, Social Problems, 21(5): 621-634.

18) Gajdosikienë, I. (2004). Oscar Lewis' Culture of Poverty Critique and Further Developmen, Sociologija. Mintis ir veiksmas, ISSN 1, 1392-3358.

19) Giddens, Anthony (1999) Runaway World : How Globalization is Reshaping our Lives, London, Profile Books 
20) Kasarda, J. D. (1990). City jobs and residents on a collision course: The urban underclass dilemma, Economic Development Quarterly, 4(4): 313-319.

21) United Nations Research Institute for Social Development (UNRISD). (2010). Combating Poverty and Inequality: Structural Change, Social Policy and Politics. 